\title{
Antioxidant and Cytotoxic Activities of Beach Morning Glory (Ipomoea pes-caprae)
}

\author{
Ashish Manigauha $^{1, *(\mathbb{D})}$, Vandana Gupta ${ }^{2}$ (D) , Narayanan Ganesh ${ }^{3(\mathbb{D})}$, Murli Dhar Kharya ${ }^{1(\mathbb{D})}$ \\ 1 Department of Pharmaceutical Sciences, Dr. Hari Singh Gour Central University, Sagar-470003, M.P., India; \\ ashish.manigaunha@gmail.com (A.M.); profkharya1975@ rediffmail.com (MD.K.); \\ 2 Mittal Institute of Pharmacy, Opposite Bhopal Memorial Hospital \&Research Centre (BMHRC), Navibagh, Karond, \\ Bhopal-462038, M.P., India; vandanargpv@ gmail.com (V.G.); \\ 3 Research Division, Jawaharlal Nehru Cancer Hospital \& Research Centre, Idgah Hills, Bhopal-462001, M.P., India; \\ nganesh_research@yahoo.co.in (N.G.); \\ * Correspondence: ashish.manigaunha@gmail.com (A.M.);
}

Scopus Author ID 26432101600

Received: 3.03.2021; Revised: 14.04.2021; Accepted: 18.04.2021; Published: 9.05.2021

\begin{abstract}
The present study aimed to evaluate the in-vitro and in-vivo antitumor potential of Ipomoea pes-caprae (I. pes-caprae). Petroleum ether $\left(60-80^{\circ} \mathrm{C}\right)$, methanol, aqueous, and swaras extracts prepared from the whole plant of I. pes-caprae. Antioxidant activity of I. pes-caprae was evaluated by using 2, 2-diphenyl-1-picrylhydrazylhydrate (DPPH), reducing power, and hydroxyl ion scavenging assay methods. The cytotoxic effect of I. pes-caprae was evaluated by using Trypan blue and 3-(4,5Dimethylthiazol-2-yl)-2,5-diphenyltetrazolium bromide (MTT) assay against animal melanoma cancer (B16F10), human stomach cancer (Kato-III), and human colorectal cancer (HT-29) cell lines. The ultraviolet (UV), infrared (IR), nuclear magnetic resonance (NMR), and Mass spectra were recorded for the structure elucidation of isolated compounds. These isolated compounds of I. pes-caprae were evaluated biologically at two doses of 25 and $12.5 \mathrm{mg} / \mathrm{kg}$ body weight on male C57BL mice to explore the antitumor activity against melanoma cancer. The scavenging range $\left(\mathrm{IC}_{50}\right)$ of the extracts of $I$. pescaprae was found to be $63.40 \pm 2.26$ to $74.77 \pm 2.28 \mu \mathrm{g} / \mathrm{ml}$, and the cytotoxic range $\left(\mathrm{CTC}_{50}\right)$ for MTT assay was found to be $62.54 \pm 3.27$ to $73.70 \pm 1.32 \mu \mathrm{g} / \mathrm{ml}$. Based on IR, NMR, and mass spectroscopic analysis and by chemical transformation, structures of three compounds $\mathrm{A}, \mathrm{B}$, and $\mathrm{C}$ were elucidated as 3'-methoxy-3,4',5,7-tetrahydroxy flavone, 3,7-dimethoxy-8-methyl-4',5-dihydroxy flavone, and 3'methoxy-4',5,7-trihydroxy flavone-3-glucoside, respectively. All isolated compounds were shown antitumor potential against melanoma cancer.
\end{abstract}

Keywords: Ipomoea pes-caprae; antioxidant; cytotoxic; MTT assay; antitumor effect; melanoma cancer.

(C) 2021 by the authors. This article is an open-access article distributed under the terms and conditions of the Creative Commons Attribution (CC BY) license (https://creativecommons.org/licenses/by/4.0/).

\section{Introduction}

Herbs have been used in the management of ailments and diseases since eternity [1]. Free radicals and reactive oxygen species have been inculpated in the etiology of many ailments. Pieces of evidence are recommending that phytopharmaceuticals are proficient in offering protection against free radicals [2]. Ipomoea pes-caprae (Convolvulaceae) is known as railroad vine, coast morning glory etc., and is pantropical that routinely colonizes sand dunes and beaches above the high tide line in tropical and subtropical regions. Conventionally $I$. pes- 
caprae has been used as first aid to treat jellyfish stings. Moreover, it is used as an antiinflammatory, antispasmodic, antihistaminic, immunostimulatory, hypoglycemic, etc. [3, 4].

Literature reviews revealed that no study had been carried out on cytotoxicity of $I$. pescaprae on melanoma cancer cells (B16F10). Therefore this study was conducted to evaluate the antitumor potential of isolated compounds from methanolic extract of Ipomoea pes-caprae on the melanoma cancer cell.

\section{Materials and Methods}

\subsection{Plant collection.}

I. pes-caprae (with its leaves, stems, and flowers) was collected from the Indian Ocean from Kuttomangalam Mandaikadu, District, Kanyakumari (T.N.) and authenticated by Botanical Survey of India (Pune) with the reference number: BSI/WC/Tech/09/447 and voucher specimen (V. No. ASIP1).

\subsection{Preparation of extract.}

Freshly constellated plant materials were shade dried, powdered, and sifted through 20 mesh size Sieve. The $100 \mathrm{~g}$ powder was successively soxhleted with petroleum ether $\left(60-80^{\circ} \mathrm{C}\right)$ and methanol. The aqueous extract was prepared by treating marc (obtained from successively soxhleted material) with lukewarm water for $24 \mathrm{~h}$ and then filtered using filter paper. The solvent from extracts was then recovered at low temperature $\left(<40^{\circ} \mathrm{C}\right)$ under reduced pressure. Swaras was prepared using fresh plant material in a mixture cum grinder and grinding it well with double distills water to convert it to pasty consistency and then to strain the paste with a thick cotton cloth. The extract so obtained was kept overnight for sedimentation, after which it was decanted and dried at ambient temperature $\left(37 \pm 2^{\circ} \mathrm{C}\right)$ to get the swaras.

\subsection{In-vitro antioxidant activity.}

\subsubsection{DPPH scavenging activity.}

The potential of $I$. pes-caprae extracts to scavenge DPPH radical was determined as per the reported method $[5,6]$. Stock solution of extracts $(1.0 \mathrm{mg} / \mathrm{ml})$ was diluted to $25,50,75$, 100 and $125 \mu \mathrm{g} / \mathrm{ml}$. Two $\mathrm{ml}$ samples solution of different concentrations was added to $1.0 \mathrm{ml}$ of $0.3 \mathrm{mM} 2$, 2-diphenyl-1-picrylhydrazylhydrate (DPPH) (Sigma Chemical Co. (St. Louis) USA) in ethanol and $2.0 \mathrm{ml}$ of phosphate buffer $(0.2 \mathrm{M}, \mathrm{pH} 7.4)$. The reaction mixture was incubated for $30 \mathrm{~min}$ in the dark at room temperature. After 30 minutes, the absorbance was recorded at $517 \mathrm{~nm}(\lambda \max )$ using UV/Visible Spectrophotometer (Shimadzu-1900, Japan). The control solution was prepared to contain water instead of extract, and a blank was prepared without the addition of DPPH. Ascorbic acid (Merck India Ltd, Mumbai, India) was used as a standard. The scavenging activity $(\%)$ was calculated using the following formula:

$$
\text { Inhibition Percentage }(I \%)=\frac{\text { Abs control- Abs test }}{\text { Abs control }} \times 100
$$

Each determination was made in triplicate. 


\subsubsection{Hydroxyl radical scavenging activity.}

The ability of extracts to scavenge hydroxyl radical was determined as per the reported method [7]. Stock solution of extracts $(1.0 \mathrm{mg} / \mathrm{ml})$ was diluted to $25,50,75,100$ and $125 \mu \mathrm{g} / \mathrm{ml}$. The reaction mixture containing $500 \mu \mathrm{l}$ solution of various concentrations of the plant extracts, $100 \mu \mathrm{l}$ of deoxyribose $\{28 \mathrm{mM}$ in phosphate buffer $0.2 \mathrm{M}$ (pH 7.4) $\}, 200 \mu 1$ of $1.04 \mathrm{mM}$ EDTA and $200 \mu \mathrm{M} \mathrm{FeCl}_{3}(0.1 \%), 100 \mu \mathrm{l}$ of $1.0 \mathrm{mM} \mathrm{H}_{2} \mathrm{O}_{2}$ and $100 \mu \mathrm{l}$ of $1.0 \mathrm{mM}$ ascorbic acid was incubated in dark at $30^{\circ} \mathrm{C}$ for $1 \mathrm{~h}$. One $\mathrm{ml}$ of (1\%) thiobarbituric acid (TBA) (Merck India Ltd, Mumbai, India) and $1.0 \mathrm{ml}$ of (10\%) trichloroacetic acid (TCA) (Merck India Ltd, Mumbai, India) were added to the reaction mixture and incubated at $100^{\circ} \mathrm{C}$ for $20 \mathrm{~min}$. After cooling, the absorbance was recorded at $532 \mathrm{~nm}(\lambda \max )$ using UV/Visible Spectrophotometer (Shimadzu-1900, Japan). The control solution was prepared to contain water instead of extract. Deoxyribose and buffer were used as a blank. Dimethyl sulfoxide (DMSO) (Merck India Ltd, Mumbai, India) was used as a standard. Percent Inhibition of deoxyribose degradation was calculated using the following formula:

Inhibition Percentage $(I \%)=\frac{\text { Abs control- Abs test }}{\text { Abs control }} \times 100$

Each determination was made in triplicate.

\subsubsection{Measurement of reductive potential.}

The reducing potential of extracts of I. pes-caprae was determined following the reported method $[8,9]$. Stock solution of the extracts $(1.0 \mathrm{mg} / \mathrm{ml})$ was diluted to $25,50,75$, 100 and $125 \mu \mathrm{g} / \mathrm{ml}$. One $\mathrm{ml}$ of a mixture of extract, $2.5 \mathrm{ml}$ of $0.2 \mathrm{M}$ phosphate buffer ( $\mathrm{pH} 7.4)$, and $2.5 \mathrm{ml}$ of $1 \%$ potassium ferricyanide $\left[\mathrm{K}_{3} \mathrm{Fe}(\mathrm{CN})_{6}\right]$ was incubated at $50^{\circ} \mathrm{C}$ for 20 minutes. $2.5 \mathrm{ml}$ of $10 \%$ trichloroacetic acid (TCA) was added to the reaction mixture and centrifuged for 10 minutes at $3000 \mathrm{rpm} .2 .5 \mathrm{ml}$ of the supernatant was diluted with $2.5 \mathrm{ml}$ water and shaken with $0.5 \mathrm{ml}$ of freshly prepared $0.1 \%$ ferric chloride. The absorbance was recorded at $700 \mathrm{~nm}$ ( $\lambda \max$ ) using UV/Visible Spectrophotometer (Shimadzu-1900, Japan). The control solution was prepared using water instead of extracts, and Ascorbic acid was used as standard. Each determination was made in triplicate.

\subsection{In-vitro cytotoxicity assay.}

\subsubsection{Cell lines.}

Animal Melanoma cancer (B16F10), Human stomach cancer (Kato-III), and Human Colorectal cancer (HT-29) cell lines (obtained from National Centre for Cell Sciences Pune, India) were inflated in $\mathrm{CO}_{2}(5 \%)$ incubator at $37^{\circ} \mathrm{C} \pm 2^{\circ} \mathrm{C}$ in MEM and RPMI 1640 medium (Himedia Laboratories Ltd., Mumbai, India) with $10 \%$ fetal bovine serum (Hi-media Laboratories Ltd., Mumbai, India). Cells were grown in standard tissue culture flasks, passed with a $0.25 \%$ trypsin-EDTA solution (Hi-media Laboratories Ltd., Mumbai, India) up to the maximum confluence.

\subsubsection{Trypan blue exclusion assay.}

Trypan blue exclusion assay was carried out as per the method described by Yuan et al. 2009 [10]. The cancer cells were seeded $\left(5 \times 10^{4}\right.$ cells) in tissue culture flasks and kept in $\mathrm{CO}_{2}$ 
incubator at $37^{\circ} \mathrm{C} \pm 2^{\circ} \mathrm{C}$. After culturing for $24 \mathrm{~h}$, the medium was changed, and $50 \mu \mathrm{l}$ of I. pescaprae extracts of concentrations $(25,50,75,100$, and $125 \mu \mathrm{g} / \mathrm{ml})$ were added to the culture flasks, keeping one flask as control (without any extract) and one flask for dacarbazine (Zydus Cadila Healthcare Ltd. India) used as standard. The flasks were then re-incubated for $48 \mathrm{~h}$, and cells buoyant in the culture medium were harvested. The tacky cells were removed with $0.05 \%$ trypsin. Then medium containing 10\% Fetal bovine serum (FBS) (and floating cells) was added to deactivate trypsin. After being withdrawn gently, the cells were centrifuged for $10 \mathrm{~min}$ at $1400 \mathrm{rpm}$. The supernatant was discarded, and the cells were collored with Trypan blue dye (Invitrogen Corporation, USA). One drop of above cell suspension was taken in a hemocytometer with bulb pipette's help and checked for the cells' viability in each flask. The viable cells were counted by using the following formula:

Viable Cells $($ per ml $)=\frac{\text { Total no.of viable cells counted }}{\text { Total no of squares }} \times$ Dilution factor $\times 10,000$

Each determination was made in triplicate.

\subsubsection{MTT-based cytotoxicity assay.}

The cytotoxic effect of the plant extracts against B16F10, Kato-III, and a rapid colorimetric assay determined HT-29 cell lines as per the reported method [11, 12]. 96-well culture plates were seeded at 10,000 cells per well and incubated in a $\mathrm{CO}_{2}$ incubator for $24 \mathrm{~h}$ at $37^{\circ} \mathrm{C}$ for their optimum population densities. After $24 \mathrm{~h}$, the experiment was carried out by adding $50 \mu \mathrm{l}$ of prepared concentrations of each extract (Stock solution of extracts $(1.0 \mathrm{mg} / \mathrm{ml}$ ) diluted to $25,50,75,100$, and $125 \mu \mathrm{g} / \mathrm{ml}$ \} in triplicate into appropriate wells and re-incubated for $72 \mathrm{~h}$ at the similar conditions. Media alone was treated as a blank and media plus cells were treated as control, and dacarbazine was used as standard. MTT (Hi-media Laboratories Ltd., Mumbai, India) solution was prepared at $5 \mathrm{mg} / \mathrm{ml}$ in phosphate buffer saline and was filtered through a $0.2 \mu \mathrm{m}$ filter. $20 \mu \mathrm{l}$ MTT solution was added to each well and mixed by tapping gently on the tray side and incubated at $37^{\circ} \mathrm{C}$ for $4 \mathrm{~h} .100 \mu \mathrm{l}$ of the old medium containing MTT was then gently replaced by $100 \mu \mathrm{DMSO}$ into each well and dissolve the formazan crystal by pipetting several times. The absorbance was measured on an ELISA plate reader (BioTek, USA) at a test wavelength of $492 \mathrm{~nm}$ and a reference wavelength of $630 \mathrm{~nm}$ to obtain a sample signal $\left(\mathrm{OD}_{492}-\mathrm{OD}_{630}\right)$. Each extract concentration was assayed in 5 wells, and the experiment was done in triplicate. The following formula determined the percentage of cell inhibition:

$$
\text { Cell Inhibition Percentage }(\mathrm{CI} \%)=\frac{\text { Abs control cells- Abs test cells }}{\text { Abs control cells }} \times 100
$$

\subsection{Fractionations and Isolation of methanolic extract of I. pes-caprae.}

The methanolic extract of I. pes-caprae was subjected to column chromatography using silica gel (60-120 mesh size), and the extract was eluted with the following solvent ratios as hexane: dichloromethane (DCM), 100:0, 80:20, 60:40, 40:60, 20:80, 0:100 respectively in a column. After that, the extract was eluted with dichloromethane (DCM): methanol gradient starting with 100:10 and additionally eluted with an increment of 5\% of methanol and was finally with $100 \%$ methanol. The fractions $(25 \mathrm{ml})$ were collected from the column. The collected elute were observed by thin-layer chromatography (eluent: DCM-MeOH, 9:1 and 3:2) for homogeneity, and the similar fraction was pooled together. The six different fractions were collected and dried. The eleven, unlike fractions, were collected and dried. The fraction 
F1 and F2 were containing waxy material; the fractions F4, F6, F7, F9, F10, and F11 were powder, but the quantity was very little. The fraction F3 was purified by column chromatogram and eluted with solvent $\mathrm{DCM}-\mathrm{MeOH}, 9: 1$. The compound was frequently rinsed with warm methanol and acetone mixture, which resulted in brown amorphous powder of compound $\mathrm{A}$. The fractions F5 and F8 were purified by column chromatogram and extracted with solvent DCM-MeOH, 9:1. The collected extract of F5 was washed with methanol. It generates compound B, while eluted compound of F8 was washed separately with acetone. They produced compound C. Fraction F10 was washed separately with acetone, and it gave compound D respectively. Different physicochemical properties further analyzed these compounds to determine the nature of the compound. Evaluation for physico-chemical properties is as melting points, UV spectra, IR spectra, NMR spectra, and Mass spectra.

\subsection{Experimental animals.}

Animals (mice) used in the present studies were procured from the Jawaharlal Nehru Cancer Hospital \& Research Centre, Bhopal. A total of 36 adult male C57BL mice of 6-8 weeks old with an average weight of 25-30 g were used for the experiments. Animals were housed in PVC cages under standard conditions $\left(12: 12 \mathrm{hrs}\right.$ light/dark cycle at $20-25^{\circ} \mathrm{C}$; relative humidity 70-75\%). Animals fed on a standard diet of mice with water ad libitum. ). The animals were divided into 6 groups randomly, including normal control and standard group (dacarbazine treated). Each group comprised 6 adult male C57BL mice. The groups have been compared, and the control group has been used in the present research. The Institutional Animal Ethical Committee approved the experimental protocol (2004/EC/2010-18.11.2010) of Research (Reg. No. 500/01/a/CPCSEA/2001), as per the guidance of the Committee for the Purpose of Control and Supervision on Experiments on Animals (CPCSEA) and institutional regulations and national criteria for animal experiments.

\subsection{Tumor induction and its measurement.}

From the tumor-bearing animal, tumors were removed aseptically. Then cell suspension was made in MEM media. Four lacks viable cells were injected intradermally on the hair removed dorsal skin of fresh mice. After 8-10 days, the tumor started growing (palpable). When the tumor was developed (Palpable), the two doses $25 \mathrm{mg} / \mathrm{kg}$ and $12.5 \mathrm{mg} / \mathrm{kg}$ body weight of different isolated compounds from methanolic extract of I. pes-caprae, were injected intraperitoneal for the whole experiment (20 days). During the treatment, the implanted tumor volume was measured regularly at a given interval of time and days with a Vernier caliper [13]. The mice were not euthanized as only tumor volume has been measured from time to time topically. Tumor volume was calculated by the formula:

Tumor volume $=(\text { shortest diameter })^{2} \mathrm{x}$ (longest diameter $) \times 0.5$

\subsection{Statistical analysis.}

Statistical analysis was carried out using the computer package SPSS version 16 (Chicago, IL). Experimental results are expressed as Means \pm SEM. All determinations were carried out in triplicates. The Common toxicity criteria 50 (CTC 50$)$ and half-maximal inhibitory concentration $\left(\mathrm{IC}_{50}\right)$ values were calculated from linear regression analysis. The significance of difference among the various treated groups and control groups was analyzed through one- 
way ANOVA followed by Dunnett's multiple comparison tests using Graphat Instat Software (San Diego, CA, USA). P values less than 0.01 were considered statistically significant.

\section{Results and Discussion}

In the present investigation, I. pes-caprae was evaluated for antioxidant ability and cytotoxic activity against different cancer cell lines by the methods of Trypan blue and MTT assay. World Health Organization (WHO) stated that more than $80 \%$ of the people worldwide trust traditional medicine for their fundamental healthcare needs. Plant-obtained materials and plant extracts are primary sources in traditional medicine due to having fewer side effects, low cost, and high availability and are essentially used to manage a wide range of disease conditions, including neoplastic disease [14-16].

Extracts with Petroleum ether $\left(60-80^{\circ} \mathrm{C}\right)$, methanol, aqueous, and swaras extracts were prepared from the whole plant of I. pes-caprae. Swaras was prepared by using fresh plant material by grinding it well with double distills water.

\subsection{In-vitro antioxidant activity.}

\subsubsection{DPPH scavenging activity.}

The quantitative DPPH assay's findings revealed the concentration-dependent antioxidant activity of I. pes-caprae (Table 1$)$. The higher concentration $(125 \mu \mathrm{g} / \mathrm{ml})$ had shown the maximum scavenging activity. Extracts of petroleum ether, methanol, aqueous, and swaras of I. pes-caprae have shown the half-maximal inhibitory concentration ( $\mathrm{IC}_{50}$ ) values as $71.27 \pm 0.28,63.40 \pm 0.26,66.00 \pm 0.31$, and $73.34 \pm 0.21 \mu \mathrm{g} / \mathrm{ml}$, respectively. The $\mathrm{IC}_{50}$ of standard DMSO was found to be $37.45 \pm 0.25 \mu \mathrm{g} / \mathrm{ml}$.

Table 1. Free radical scavenging activity of I. pes-caprae.

\begin{tabular}{|c|c|c|c|c|c|c|}
\hline \multirow{2}{*}{ Test substance } & \multicolumn{6}{|c|}{ Concentration $(\mu \mathrm{g} / \mathrm{ml})$} \\
\hline & 25 & 50 & 75 & 100 & 125 & $\begin{array}{c}\text { IC50 } \\
(\mu \mathrm{g} / \mathrm{ml})\end{array}$ \\
\hline $\begin{array}{c}\text { DPPH Assay } \\
\text { DMSO a }\end{array}$ & $44.46 \pm 3.15$ & $57.23 \pm 3.21$ & $68.29 \pm 4.24$ & $78.08 \pm 3.16$ & $97.63 \pm 3.13$ & $37.45 \pm 3.25$ \\
\hline Pet. ether extract & $24.62 \pm 2.36$ & $41.50 \pm 3.31$ & $50.78 \pm 3.42$ & $65.31 \pm 3.36$ & $77.63 \pm 3.41$ & $71.27 \pm 4.28$ \\
\hline Methanol extract & $30.41 \pm 3.30$ & $42.32 \pm 4.25$ & $54.25 \pm 2.36$ & $69.55 \pm 4.40$ & $85.63 \pm 2.23$ & $63.40 \pm 3.26$ \\
\hline Aqueous extract & $27.86 \pm 2.37$ & $43.69 \pm 3.31$ & $52.41 \pm 3.41$ & $67.42 \pm 3.37$ & $82.63 \pm 2.31$ & $66.00 \pm 2.31$ \\
\hline Swaras & $20.96 \pm 2.37$ & $39.41 \pm 2.37$ & $52.55 \pm 3.30$ & $66.24 \pm 2.43$ & $75.63 \pm 3.33$ & $73.34 \pm 3.21$ \\
\hline $\begin{array}{c}\text { Hydroxyl radical Assay } \\
\text { DMSO a }\end{array}$ & $43.76 \pm 3.23$ & $56.74 \pm 3.20$ & $66.34 \pm 3.21$ & $77.43 \pm 3.25$ & $96.53 \pm 4.23$ & $39.10 \pm 2.19$ \\
\hline Pet. ether extract & $26.77 \pm 2.10$ & $34.33 \pm 4.12$ & $49.14 \pm 2.22$ & $65.61 \pm 2.28$ & $78.65 \pm 3.23$ & $73.37 \pm 3.36$ \\
\hline Methanol extract & $28.26 \pm 3.21$ & $36.95 \pm 4.10$ & $51.48 \pm 2.11$ & $68.14 \pm 4.20$ & $84.43 \pm 2.13$ & $68.31 \pm 2.25$ \\
\hline Aqueous extract & $29.13 \pm 3.08$ & $43.40 \pm 3.14$ & $52.79 \pm 2.18$ & $67.29 \pm 2.17$ & $85.53 \pm 3.14$ & $64.79 \pm 3.21$ \\
\hline Swaras & $24.44 \pm 2.15$ & $33.71 \pm 2.25$ & $47.09 \pm 3.18$ & $64.93 \pm 3.28$ & $80.63 \pm 2.33$ & $74.77 \pm 3.28$ \\
\hline
\end{tabular}

\subsubsection{Hydroxyl radical scavenging activity.}

This assay showed the potentiality of I. pes-caprae and DMSO's tested extracts as antioxidants (Table 1). The higher concentration $(125 \mu \mathrm{g} / \mathrm{ml})$ had shown a higher percentage of inhibition for all the extracts. $\mathrm{IC}_{50}$ values of petroleum ether, methanol, aqueous, and swaras extracts of $I$. pes-caprae and standard were found to be $73.37 \pm 0.36,68.31 \pm 0.25,64.79 \pm 0.21$, $74.77 \pm 0.28$, and $39.10 \pm 0.19 \mu \mathrm{g} / \mathrm{ml}$, respectively. 


\subsubsection{Measurement of reductive ability.}

The $\mathrm{Fe}^{3+}$ to $\mathrm{Fe}^{2+}$ ions transformation in the presence of the extracts was investigated to measure the reductive ability (Table 2). The absorbance values of petroleum ether, methanol, aqueous and swaras extracts of $I$. pes-caprae and standard at the higher concentration $(125 \mu \mathrm{g} / \mathrm{ml})$ were found to be $0.814 \pm 1.25,0.856 \pm 2.27,0.838 \pm 2.31,0.726 \pm 2.23$, and $0.982 \pm 0.22 \mu \mathrm{g} / \mathrm{ml}$, respectively.

Table 2. Free radical scavenging activity of I. pes-caprae by reducing ability assay.

\begin{tabular}{|c|c|c|c|c|c|}
\hline \multirow[t]{2}{*}{ Test Substance } & \multicolumn{5}{|c|}{ Concentration $(\mu \mathrm{g} / \mathrm{ml})$} \\
\hline & 25 & 50 & 75 & 100 & 125 \\
\hline Ascorbic acid ${ }^{\mathbf{a}}$ & $0.618 \pm 0.08$ & $0.671 \pm 0.02$ & $0.754 \pm 0.06$ & $0.832 \pm 0.05$ & $0.982 \pm 0.02$ \\
\hline Pet. ether extract & $0.495 \pm 0.03$ & $0.565 \pm 0.07$ & $0.657 \pm 0.07$ & $0.723 \pm 0.04$ & $0.814 \pm 0.05$ \\
\hline Methanol extract & $0.524 \pm 0.07$ & $0.614 \pm 0.05$ & $0.674 \pm 0.03$ & $0.768 \pm 0.06$ & $0.856 \pm 0.07$ \\
\hline Aqueous extract & $0.545 \pm 0.02$ & $0.637 \pm 0.09$ & $0.689 \pm 0.05$ & $0.752 \pm 0.03$ & $0.838 \pm 0.08$ \\
\hline Swaras & $0.480 \pm 0.05$ & $0.532 \pm 0.04$ & $0.583 \pm 0.03$ & $0.630 \pm 0.07$ & $0.726 \pm 0.04$ \\
\hline
\end{tabular}

An antioxidant is capable of reducing and preventing the oxidation of other molecules or moieties. In a biological environment, antioxidants can protect cells from damage caused by unstable molecules. They are supposed to play a role in preventing the development of chronic diseases such as cancer, heart diseases, stroke, Alzheimer's, rheumatoid arthritis etc. [17]. The quantitative DPPH assay results revealed the concentration-dependent antioxidant activity of I. pes-caprae. DPPH assay revealed a lesser $\mathrm{IC}_{50}$ value for methanolic extract. Basically, a higher DPPH radical-scavenging activity is associated with a lower IC50 value. Hydroxyl radical scavenging assay showed the potentiality of the $I$. pes-caprae extracts to inhibit hydroxyl radical-mediated deoxyribose degradation in $\mathrm{Fe}^{3+}$ - EDTA-ascorbic acid and $\mathrm{H}_{2} \mathrm{O}_{2}$ reaction mixture. Aqueous extract of I. pes-caprae shows maximum scavenging capacity for hydroxyl radical among all the extracts. The change of yellow color of the test solution to various shades of blue and green, depending on the extract's concentration, indicates antioxidant activity. The increasing concentration of $I$. pes-caprae extracts and ascorbic acid shows increased absorbance, indicating reducing potential. The reducing potential of a compound mostly depends on reluctance, which has exhibited antioxidative potential by breaking chain reaction and donating a hydrogen atom.

\subsection{In-vitro cytotoxicity assay.}

\subsubsection{Trypan blue exclusion assay.}

\subsubsection{Effect on B16F10 cancer cell line.}

The percentage inhibition of $\mathrm{B} 16 \mathrm{~F} 10$ by the various extracts of $I$. pes-caprae was found to be concentration-dependent and compared favorably with dacarbazine (Table 3). Dacarbazine solution and aqueous, methanol, petroleum ether, swaras extracts of I. pes-caprae and control had the values of viable cells $/ \mathrm{ml}$ at the concentration of $125 \mu \mathrm{g} / \mathrm{ml} 1.01 \times 10^{4}$, $1.50 \times 10^{4}, 1.58 \times 10^{4}, 1.65 \times 10^{4}, 1.72 \times 10^{4}$, and $5 \times 10^{4}$ respectively.

\subsubsection{Effect on Kato-III cancer cell line.}

Cytotoxic activity of the extracts of I. pes-caprae was reflected as the \% inhibition of Kato-III cancer cell line (Table 3). The values for viable cells $/ \mathrm{ml}$ at $125 \mu \mathrm{g} / \mathrm{ml}$ concentration were found $1.07 \times 10^{4}, 1.60 \times 10^{4}, 1.63 \times 10^{4}, 1.65 \times 10^{4}, 1.70 \times 10^{4}$ and $5 \times 10^{4}$ for the dacarbazine 
solution and aqueous, methanol, petroleum ether, swaras extracts of I. pes-caprae and control respectively.

Table 3. Cytotoxic effect of I. pes-caprae by Trypan blue exclusion assay.

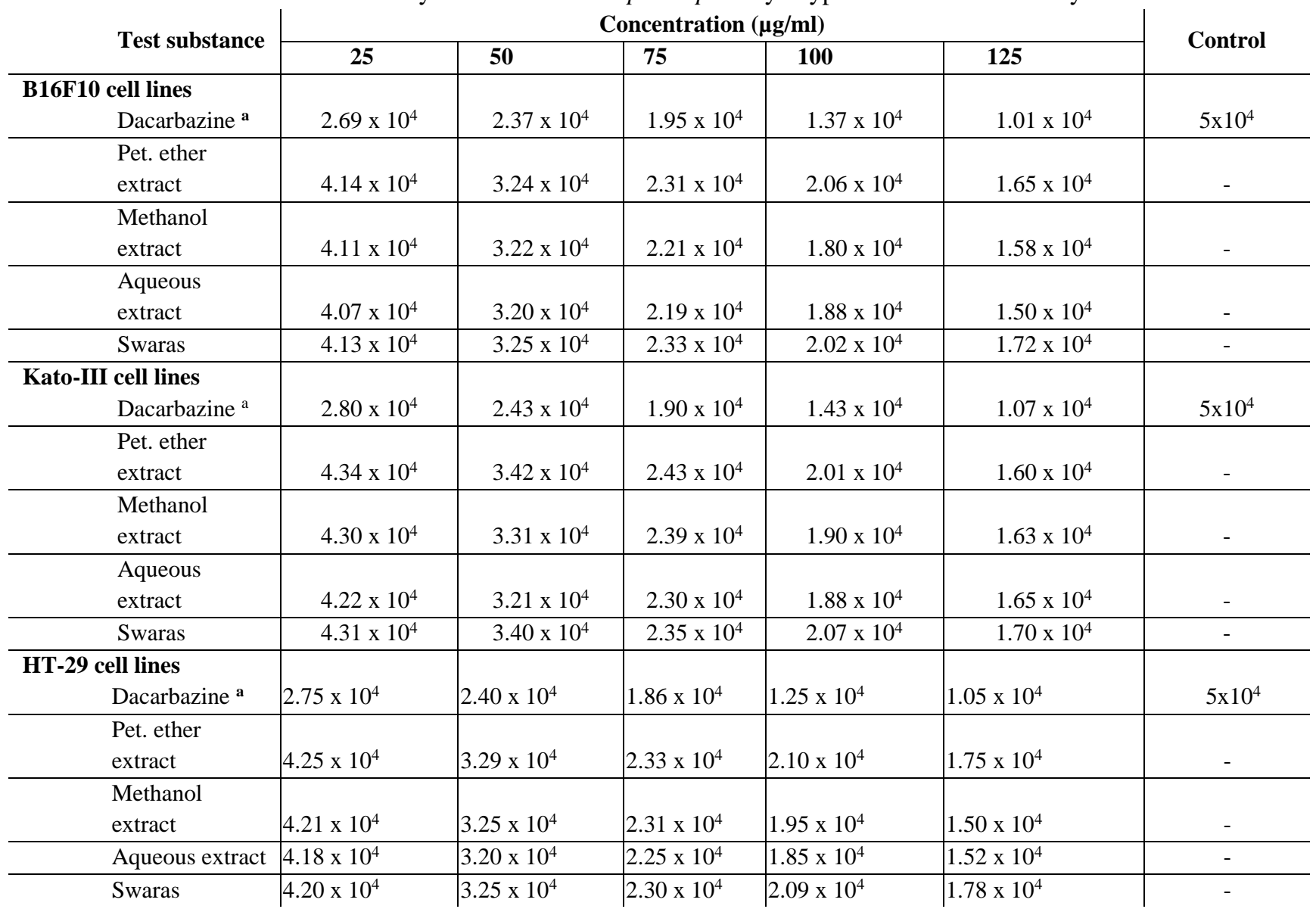

Results (Viability of cells/ml), $(\mathrm{n}=3),{ }^{\text {a }}$ A Reference compound.

\subsubsection{Effect on HT-29 cancer cell line}

Cytotoxic activity of the extracts of I. pes-caprae against HT-29 cancer cell line (Table 3) was found to be in the order of dacarbazine $\left(1.05 \times 10^{4}\right)>$ methanol $\left(1.50 \times 10^{4}\right)>$ aqueous $\left(1.52 \times 10^{4}\right)>$ petroleum ether $\left(1.75 \times 10^{4}\right)$ extracts $>$ swaras $\left(1.78 \times 10^{4}\right)>$ control $\left(5 \times 10^{4}\right)$ cells $/ \mathrm{ml})$. The data of $I$. pes-caprae extracts on HT-29 cell line was in the order of dacarbazine $>$ methanol $>$ aqueous $>$ petroleum ether $>$ swaras and $>$ control cells $/ \mathrm{ml}$. The considerable differences were found in the $\%$ inhibition of cancer cell lines at the different concentrations of extracts used.

\subsubsection{MTT-based cytotoxicity assay.}

The MTT assay is based on the cleavage of the yellow tetrazolium salt MTT to purple formazan crystal by active metabolic cells through mitochondrial succinate dehydrogenase. The MTT enters the cells and passes into the mitochondria, where it is reduced to an insoluble, colored formazan product. The formazan is then solubilized, and the concentration is measured spectrophotometrically. 


\subsubsection{Effect on B16F10 cancer cell line.}

The cytotoxic effect of I. pes-caprae on B16F10 cancer cell line by MTT assay method compared with the standard dacarbazine is presented in Table 4. The $\mathrm{CTC}_{50}$ values for dacarbazine solution and aqueous, methanol, petroleum ether, and swaras extracts of $I$. pescaprae were $38.05 \pm 0.21,62.54 \pm 0.27,64.93 \pm 0.18,71.86 \pm 0.25$, and $72.25 \pm 0.31 \mu \mathrm{g} / \mathrm{ml}$, respectively. The cytotoxic effect of the $I$. pes-caprae extracts against B16F10 cell line was significantly lower than the standard drug expressed as dacarbazine $>$ aqueous $>$ methanolic $>$ petroleum ether $>$ swaras.

Table 4. Cytotoxic effect of I. pes-caprae by MTT assay.

\begin{tabular}{|c|c|c|c|c|c|c|}
\hline \multirow[t]{2}{*}{ Test substance } & \multicolumn{6}{|c|}{ Concentration $(\mu \mathrm{g} / \mathrm{ml})$} \\
\hline & 25 & 50 & 75 & 100 & 125 & IC50 $(\mu \mathrm{g} / \mathrm{ml})$ \\
\hline $\begin{array}{l}\text { B16F10 cell lines } \\
\text { Dacarbazine a }^{\text {a }}\end{array}$ & $42.28 \pm 3.28$ & $56.29 \pm 3.29$ & $70.24 \pm 4.16$ & $87.17 \pm 3.25$ & $95.18 \pm 4.23$ & $38.05 \pm 3.21$ \\
\hline $\begin{array}{l}\text { Pet. ether } \\
\text { extract }\end{array}$ & $21.34 \pm 3.15$ & $40.28 \pm 4.24$ & $53.32 \pm 4.13$ & $65.49 \pm 2.25$ & $78.57 \pm 4.22$ & $71.86 \pm 2.25$ \\
\hline $\begin{array}{l}\text { Methanol } \\
\text { extract }\end{array}$ & $25.13 \pm 2.22$ & $45.38 \pm 3.15$ & $55.24 \pm 3.19$ & $67.58 \pm 3.21$ & $85.56 \pm 3.23$ & $64.93 \pm 4.18$ \\
\hline $\begin{array}{l}\text { Aqueous } \\
\text { extract }\end{array}$ & $30.29 \pm 3.25$ & $43.29 \pm 2.18$ & $56.23 \pm 2.15$ & $68.17 \pm 4.22$ & $86.27 \pm 3.12$ & $62.54 \pm 4.27$ \\
\hline Swaras & $19.94 \pm 2.14$ & $42.70 \pm 3.18$ & $50.88 \pm 3.21$ & $66.11 \pm 3.11$ & $78.31 \pm 2.22$ & $72.25 \pm 3.31$ \\
\hline $\begin{array}{c}\text { Kato-III cell lines } \\
\text { Dacarbazine }^{a}\end{array}$ & $43.35 \pm 3.23$ & $60.20 \pm 3.21$ & $76.34 \pm 2.17$ & $85.65 \pm 3.16$ & $96.18 \pm 3.23$ & $32.42 \pm 3.18$ \\
\hline $\begin{array}{l}\text { Pet. ether } \\
\text { extract }\end{array}$ & $26.34 \pm 2.16$ & $43.67 \pm 4.22$ & $52.34 \pm 3.19$ & $62.34 \pm 4.17$ & $75.48 \pm 3.21$ & $70.79 \pm 3.28$ \\
\hline $\begin{array}{l}\text { Methanol } \\
\text { extract }\end{array}$ & $21.34 \pm 4.22$ & $46.10 \pm 3.21$ & $55.31 \pm 2.18$ & $70.67 \pm 2.16$ & $86.27 \pm 2.24$ & $65.46 \pm 4.21$ \\
\hline $\begin{array}{l}\text { Aqueous } \\
\text { extract }\end{array}$ & $23.10 \pm 3.18$ & $41.67 \pm 3.17$ & $52.67 \pm 3.23$ & $67.00 \pm 4.14$ & $87.58 \pm 2.21$ & $67.88 \pm 2.31$ \\
\hline Swaras & $24.34 \pm 2.13$ & $38.67 \pm 2.22$ & $54.34 \pm 4.21$ & $65.34 \pm 3.17$ & $74.21 \pm 4.19$ & $72.37 \pm 2.35$ \\
\hline $\begin{array}{l}\text { HT-29 cell lines } \\
\text { Dacarbazine a }\end{array}$ & $40.45 \pm 3.21$ & $58.67 \pm 3.18$ & $73.43 \pm 3.14$ & $83.56 \pm 4.21$ & $94.18 \pm 3.23$ & $37.14 \pm 4.21$ \\
\hline $\begin{array}{l}\text { Pet. ether } \\
\text { extract }\end{array}$ & $19.65 \pm 4.25$ & $43.78 \pm 4.13$ & $56.45 \pm 4.14$ & $65.22 \pm 2.18$ & $78.49 \pm 4.22$ & $70.17 \pm 3.27$ \\
\hline $\begin{array}{l}\text { Methanol } \\
\text { extract }\end{array}$ & $24.42 \pm 2.21$ & $47.67 \pm 4.19$ & $52.42 \pm 2.17$ & $69.56 \pm 4.15$ & $88.18 \pm 4.12$ & $64.28 \pm 2.32$ \\
\hline $\begin{array}{l}\text { Aqueous } \\
\text { extract }\end{array}$ & $22.55 \pm 3.17$ & $46.63 \pm 3.21$ & $54.23 \pm 3.19$ & $67.78 \pm 3.15$ & $83.54 \pm 2.20$ & $66.43 \pm 4.24$ \\
\hline Swaras & $19.45 \pm 2.19$ & $39.11 \pm 2.14$ & $55.42 \pm 4.09$ & $63.65 \pm 3.21$ & $76.12 \pm 4.11$ & $73.70 \pm 2.32$ \\
\hline
\end{tabular}

3.2.2.2. Effect on Kato-III cancer cell line.

The cytotoxic effect of I. pes-caprae against Kato-III cancer cell line by MTT method was concentration-dependent (Table 4). The cytotoxicity (CTC50) values for dacarbazine solution and methanol, aqueous, petroleum ether, and swaras extract of $I$. pes-caprae were $32.42 \pm 0.18,65.46 \pm 0.21,67.88 \pm 0.31,70.79 \pm 0.28$, and $72.37 \pm 0.35 \mu \mathrm{g} / \mathrm{ml}$, respectively. The percentage inhibition of Kato-III by various extracts and the standard drug was in the decreasing order: Dacarbazine $>$ methanolic $>$ aqueous $>$ petroleum ether $>$ swaras.

\subsubsection{Effect on HT-29 cancer cell line.}

Cytotoxic activity of extracts of I. pes-caprae was tested for HT-29 cancer cell line by MTT assay (Table 4). The $\mathrm{CTC}_{50}$ values were found $37.14 \pm 0.21,64.28 \pm 0.32,66.43 \pm 0.24$, $70.17 \pm 0.27$, and $73.70 \pm 0.32 \mu \mathrm{g} / \mathrm{ml}$ for the dacarbazine solution and methanol, aqueous, petroleum ether, and swaras extract of I. pes-caprae, respectively. The percentage inhibition of 
HT-29 by the extracts and the standard drug was noted in decreasing order: Dacarbazine > methanolic $>$ aqueous $>$ petroleum ether $>$ swaras.

The cytotoxic inhibition of the cancer cell line by the extracts and swaras was concentration-dependent and differed significantly. Studies with plants involve screening for biological activity followed by pharmacological assays of their extracts. Earlier studies have revealed that Convolvulaceae members possess cytotoxic effects against a number of tumor cells. In the case of the Trypan blue assay, the cytotoxic activity of I. pes-caprae against B16F10 cell line was in the order of dacarbazine $>$ aqueous $>$ methanol $>$ petroleum ether $>$ swaras and $>$ control. The $\%$ inhibition of the Kato-III cell line by the I. pes-caprae extracts varied significantly from that of control. The data of $I$. pes-caprae extracts as compared with dacarbazine were in the order of dacarbazine $>$ petroleum ether $>$ methanol $>$ aqueous $>$ swaras and $>$ control. The reduction of MTT can only occur in metabolically active cells, and the level of activity is a measure of the viability of the cells. Cell viability assay measures the number of living cells in the sample. It is based on the principle that living cells possess intact cell membrane that excludes certain dyes, such as Trypan blue, whereas dead cells do not $[18,19]$. The potent compound responsible for cytotoxic activity present in methanolic extract of Ipomoea aquatica was a poly-phenolic compound [20], whereas in I. stan and I. murucoids the lipophilic glycosides were responsible for cytotoxic activity of nonpolar extracts [21].

\subsection{Methanolic extract of Ipomoea pes-caprae.}

Methanolic extract of $I$. pes-caprae, which has not been previously chemically investigated, was found four new compounds Compound A, B, C, and D, but the fourth compound, compound D, structurally not elucidated (Figure 1).
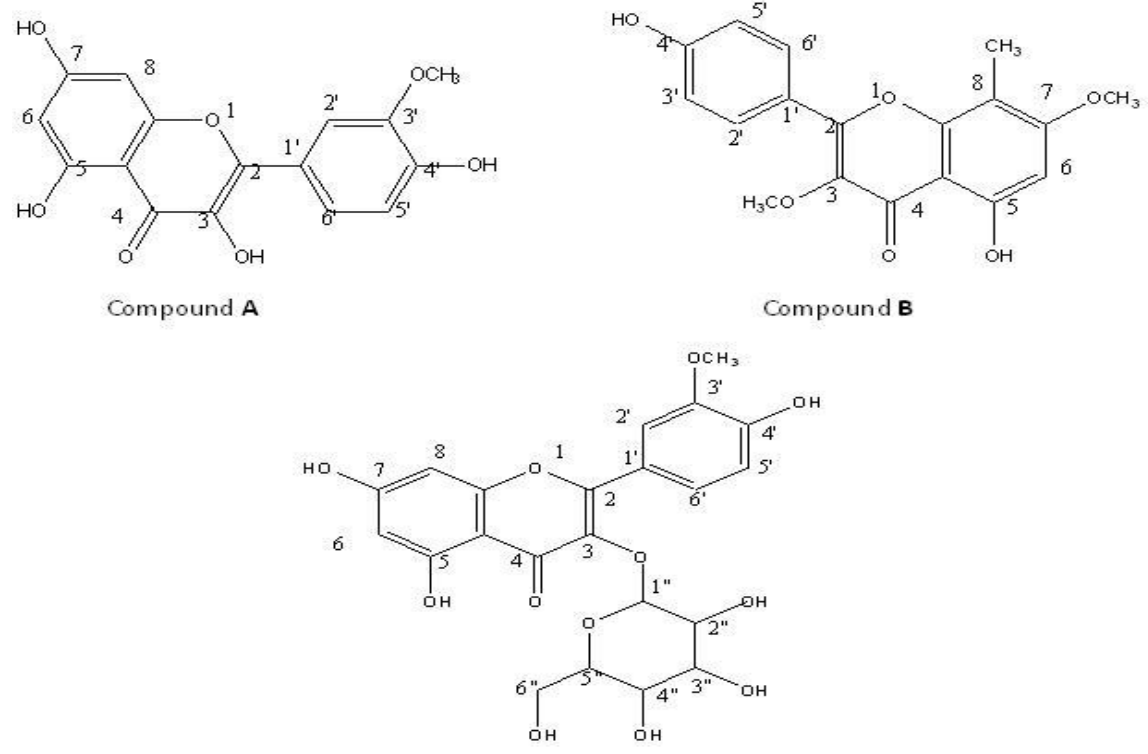

Compound C

Figure 1. The chemical structure of isolated compounds from methanolic extract of Ipomoea pes-caprae. \{Compoud A (3'-methoxy-3,4',5,7-tetrahydroxy flavone), Compound B (3,7-dimethoxy-8-methyl-4',5dihydroxy flavone) and Compound C (3'-methoxy-4',5,7-trihydroxy flavone-3-glucoside)\}.

Compound A was procured as amorphous powder and it shown positive tests for flavonoids. Its melting point was found to be $276-279{ }^{\circ} \mathrm{C}$. It gave UV $\lambda$ max (MeOH) $(\mathrm{nm}): 460.0$. The IR $\left(\mathrm{v} \mathrm{cm}^{-1}\right)$ spectrum (Figure 2) of compound showed absorption at 3874.1 (Hydrogen bonding), 3779.1, 3421.4 and 3341.3 (O-H, free hydroxyl group), 3022.0 (Cyclic C-H, str), 
2924.2 (Ali- C-H, str), 2856.7 ( $\mathrm{CH}_{2}$ symmetric stretching), $1721.0(\mathrm{C}=\mathrm{O}), 1603.7,1520.5$ and 1435.4 (C-C stretching), 1216.3 (C-C stretching), 929.0 (O-H, out of plane bend), 762.8 and 671.1 (monosubstituted in aromatic ring), 568.1 and 501.9. The ${ }^{1} \mathrm{H}$ NMR spectrum (Figure 3) of compound displayed the characteristic signals at $\delta_{\mathrm{H}} 5.4\left(\mathrm{OH}-4{ }^{\prime}, \mathrm{s}\right), 5.1(\mathrm{OH}-5, \mathrm{~s}), 5.2(\mathrm{OH}-7$, s), $5.0(\mathrm{OH}-3, \mathrm{~s}), 3.73\left(\mathrm{OCH}_{3}-3\right.$ ', s), $6.64(\mathrm{H}-2$ ', s), 6.57 (H-5', d), 5.95 to 5.98- (H-6,8, s), 6.69 $\left(\mathrm{H}-6\right.$ ', d). The ${ }^{13} \mathrm{C}$ NMR spectrum (Figure 4 ) of compound displayed the characteristic signals at $2-160.57,3-138.65,4-179.06,5-163.29,6-97.87,7-166.25,8-97.28,1$ '-123.55, 8a-160.1, 4a-105.76, 2'-112.28, 3'-151.13, 4'-144.12, $\mathrm{OCH}_{3}-56.81,5$ '-116.16, 6'-121.01.

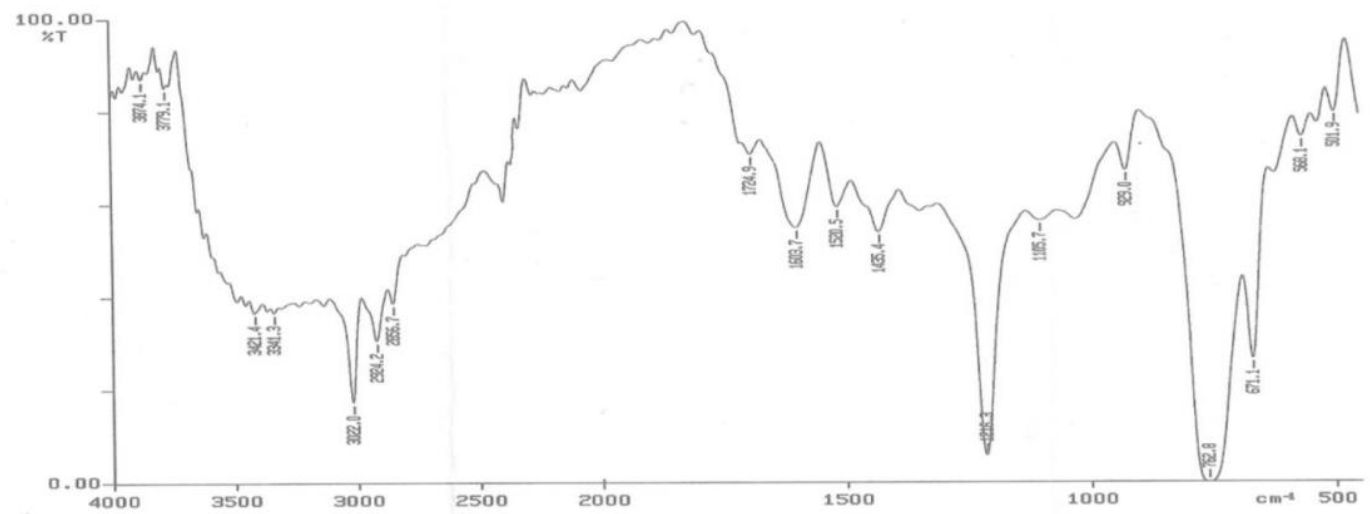

Figure 2. FTIR Spectra of compound A. FT-IR study of compound A and its characteristics absorption spectrum. Spectra show the characteristics absorption peaks of the various functional group present in compound A.

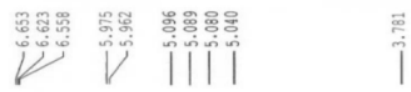

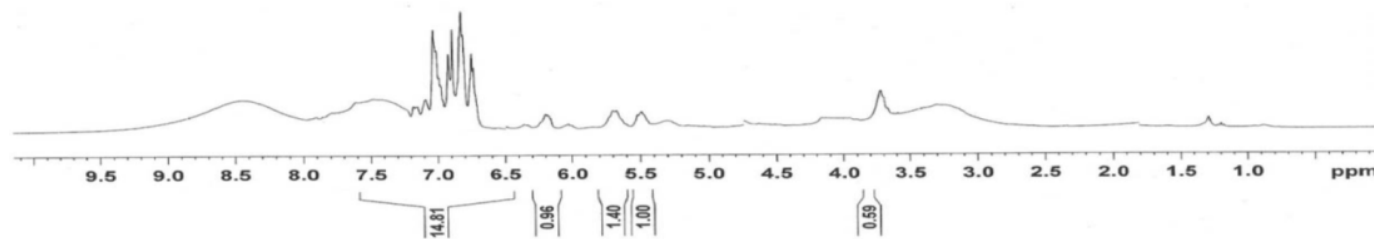

Figure 3. ${ }^{1} \mathrm{H}$ NMR Spectra of compound A. ${ }^{1} \mathrm{H}$ NMR study of compound A displayed the characteristic signals.

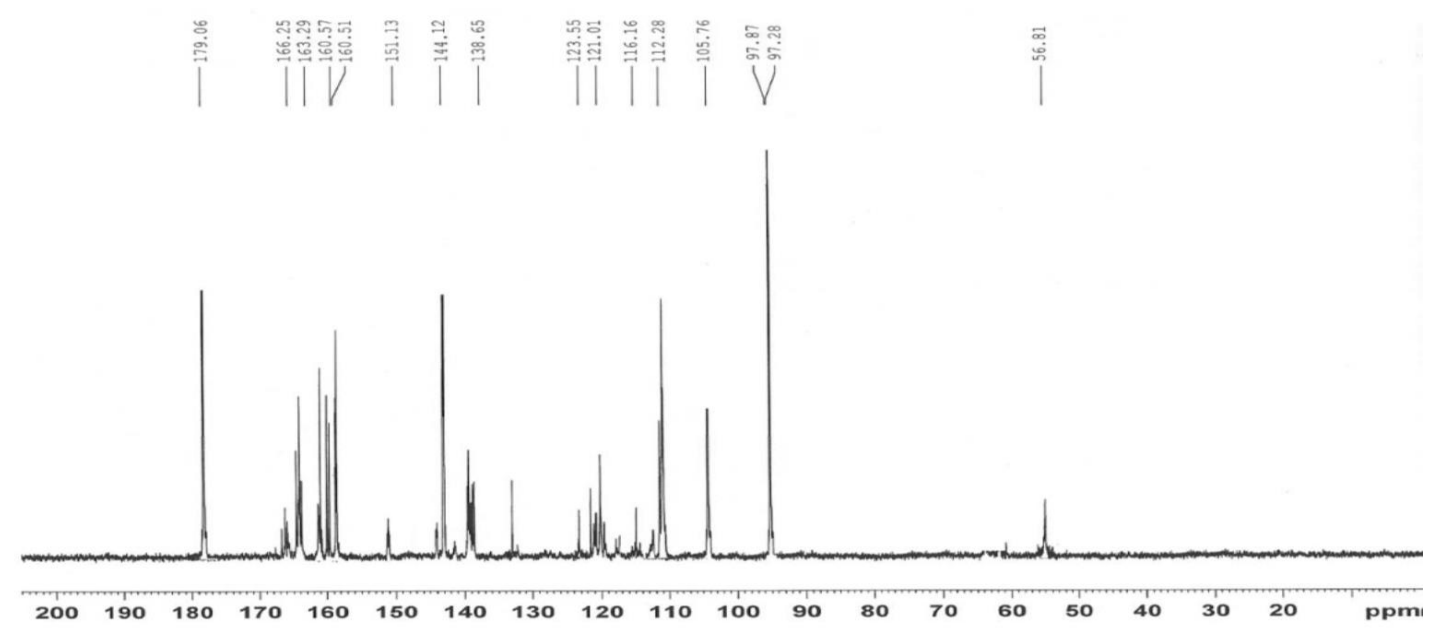

Figure 4. ${ }^{13} \mathrm{C}$ NMR Spectra of compound A. ${ }^{13} \mathrm{C}$ NMR study of compound A displayed the characteristic signals. 
The mass data (Figure 5) which showed $\mathrm{m} / \mathrm{z}=316(100)\left[\mathrm{M}^{+}\right]$indicative of $\mathrm{C}_{16} \mathrm{H}_{12} \mathrm{O}_{7}$. Molecular formula of Compound A was determined as $\mathrm{C}_{16} \mathrm{H}_{12} \mathrm{O}_{7}\left\{\mathrm{~m} / \mathrm{z}=316(100)\left[\mathrm{M}^{+}\right]\right\}$.

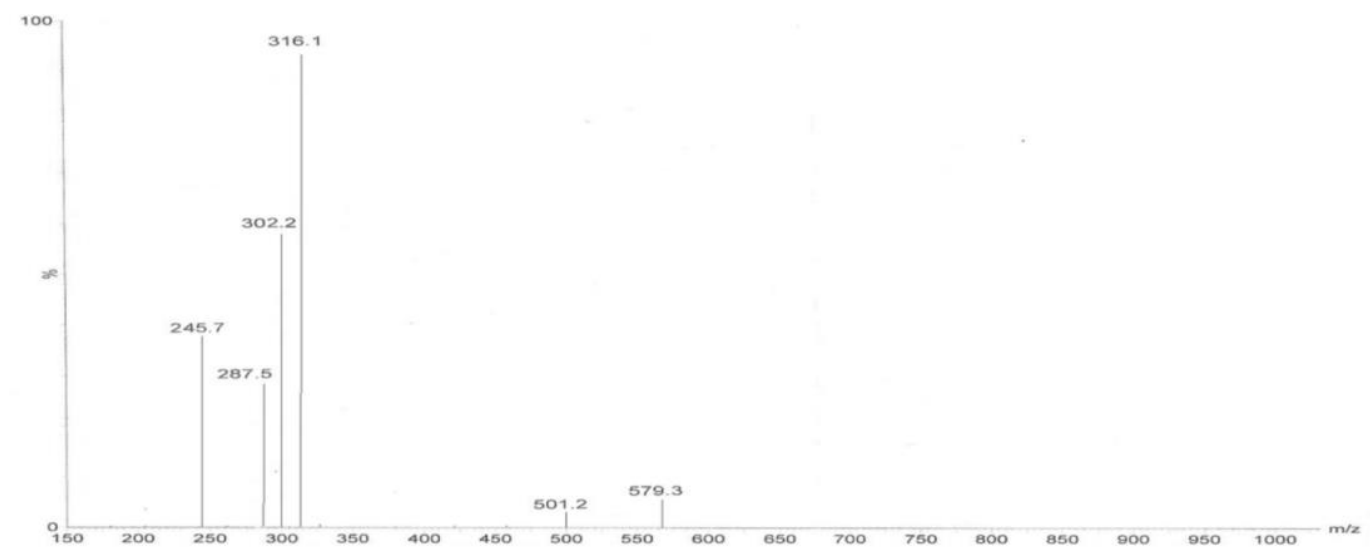

Figure 5. Mass Spectra of compound A. The mass data of compound A shows characteristic peaks.

Compound A (3'-methoxy-3,4',5,7-tetrahydroxy flavone). The molecular formula of $\mathrm{C}_{16} \mathrm{H}_{12} \mathrm{O}_{7}$ was procured from the ES-MS $\left[\mathrm{M}^{+}\right]$at $\mathrm{m} / \mathrm{z} 316$ and the ${ }^{1} \mathrm{H}$ NMR and ${ }^{13} \mathrm{C}$ NMR spectral analysis. Furthermore, the IR spectrum indicated absorptions attributable to free hydroxyl $\left(3341.3 \mathrm{~cm}^{-1}\right)$ and ketone $\left(1721.0 \mathrm{~cm}^{-1}\right)$ groups. An examination of its NMR data and a comparison with the literature revealed that compound A was a flavone. The most downfield shifted peak was $179.06 \mathrm{ppm}$ which was assigned ketone group (C-4). The downfield shifted peak $160.57 \mathrm{ppm}$ and $123.55 \mathrm{ppm}$ were $\mathrm{C}-2$ and C-1' respectively due absence of proton, and it indicates that C-2 and C-1' were attached by a ring. This may further be confirmed by the presence of C-2' and C-6' shifted peaks at 112.28 and 121.01 ppm, respectively. In addition, this was favored by the doublet peak of ${ }^{1} \mathrm{H}$ NMR spectrum for H-2' and H-6' at 6.62 and 6.65, respectively, due to the methine group. Thus, its ${ }^{1} \mathrm{H}$ NMR spectrum revealed characteristic resonances of aromatic protons such as $\mathrm{H} 6$ and $\mathrm{H} 8(\delta 5.96, \mathrm{~s})$, and this aromatic proton is confirmed by the ${ }^{13} \mathrm{C}$ NMR peaks of C- 6 and C- 8 produces at $\delta 97.28 \mathrm{ppm}$. Here reduction in downfield peak is due to resonance of hydroxyl group present at associated carbon. The multiplicities and the weak coupling constants of $\mathrm{H} 6$ and $\mathrm{H} 8$ were in agreement with the existence of the hydroxyl group at C7 ( $\delta 166.25)$ and C-5 ( $\delta$ 163.9). A typical methoxyl signal at $\delta 3.78 \mathrm{ppm}$ was also observed at C-3'. This methoxy group resonance with $\mathrm{C}-3$ ' and produces signals at $\delta 151.13 \mathrm{ppm}$. The presence in the ${ }^{1} \mathrm{H}$ NMR spectrum of signals at $\delta 5.0 \mathrm{ppm}$ reveals the presence of hydroxyl group at $\mathrm{H}-3$ and $\mathrm{H}-4$ ' in conjunction with the ${ }^{13} \mathrm{C}$ NMR signals at $\delta$ 136.1 and $144.9 \mathrm{ppm}$. The presence in the ${ }^{1} \mathrm{H}$ NMR spectrum of signals at $\delta 6.55 \mathrm{ppm}$ in conjunction with the ${ }^{13} \mathrm{C}$ NMR signals at $\delta 116.16 \mathrm{ppm}$. The compound is characterized as 3'methoxy-3,4',5,7-tetrahydroxy flavone.

Compound B was procured as amorphous powder and it shown positive tests for flavonoids. Its melting point was found to be $279-283^{\circ} \mathrm{C}$. It gave UV $\lambda$ max (MeOH) (nm): 460.0. The IR ( $\left.\mathrm{v} \mathrm{cm}^{-1}\right)$ spectrum (Figure 6) of compound B showed absorption bands at 3962.2 and 3905.5 (Hydrogen bonding), 3756.0 to 3236.8 (O-H, free hydroxyl group), 3021.8 (Cyclic CH, str), 2926.2 (Ali- C-H, str), 1724.9 (C=O, Ketone), 1661.4 (C=C stretch), 1589.3, 1472.3 and 1431.7 (C-C ring stretch), 1216.6 (C-C stretching), 1024.3 (C-O-C), 929.4 (O-H, out of plane bend), 763.1 and 671.9 (monosubstituted in aromatic ring), 541.7 and 486.2 (out of plane ring $\mathrm{C}=\mathrm{C}$, bend). The ${ }^{1} \mathrm{H}$ NMR spectrum (Figure 7) of compound displayed the characteristic signals at $\delta_{\mathrm{H}} 5.07\left(\mathrm{OH}-4{ }^{\prime}, \mathrm{s}\right), 5.07(\mathrm{OH}-5, \mathrm{~s}), 3.78\left(\mathrm{OCH}_{3}-3, \mathrm{~s}\right), 3.78\left(\mathrm{OCH}_{3}-7, \mathrm{~s}\right), 2.36\left(\mathrm{CH}_{3}, \mathrm{~s}\right)$, 7.19 (H-2', d), 7.16 (H-6', d), 5.81 (H-6, s), 6.68 (H-5', d), 6.68 (H-3', d). The ${ }^{13} \mathrm{C}$ NMR 
spectrum (Figure 8) of compound displayed the characteristic signals at 2-156.06, 3-138.65, 4178.97, 5-160.51, 6-96.91, 7-166.84, 8-106.91, 1'-123.55, 8a-160.28, 4a-105.76, 2'-127.98, 3'-115.60, 4'-156.88, $\mathrm{OCH}_{3}-51.75,5$ '-115.60, 6'-127.60, $\mathrm{OCH}_{3}-56.48, \mathrm{CH}_{3}-47.87$. The mass data (Figure 9) which showed $\mathrm{m} / \mathrm{z}=328(100)\left[\mathrm{M}^{+}\right]$indicative of $\mathrm{C}_{18} \mathrm{H}_{16} \mathrm{O}_{6}$. The molecular formula of Compound $\mathrm{B}$ was determined as $\mathrm{C}_{18} \mathrm{H}_{16} \mathrm{O}_{6}\left\{\mathrm{~m} / \mathrm{z}=328(100)\left[\mathrm{M}^{+}\right]\right\}$.

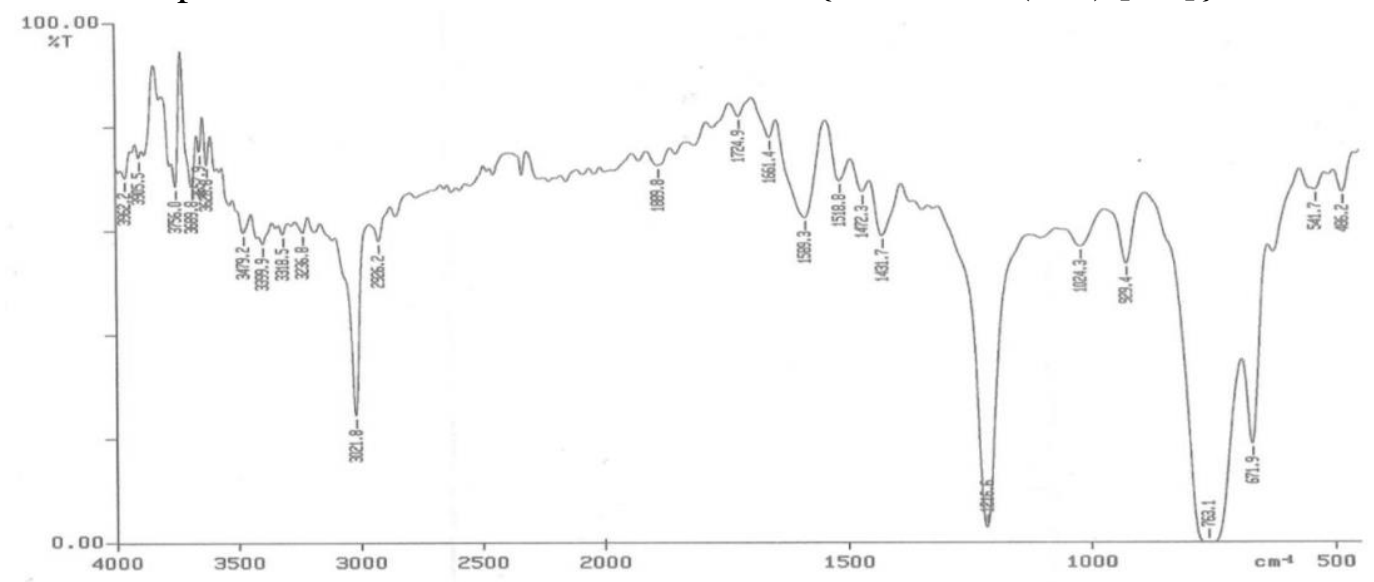

Figure 6. FTIR Spectra of compound B. FT-IR study of compound B and its characteristics absorption spectrum. Spectra show the characteristics absorption peaks of the various functional group present in compound A.

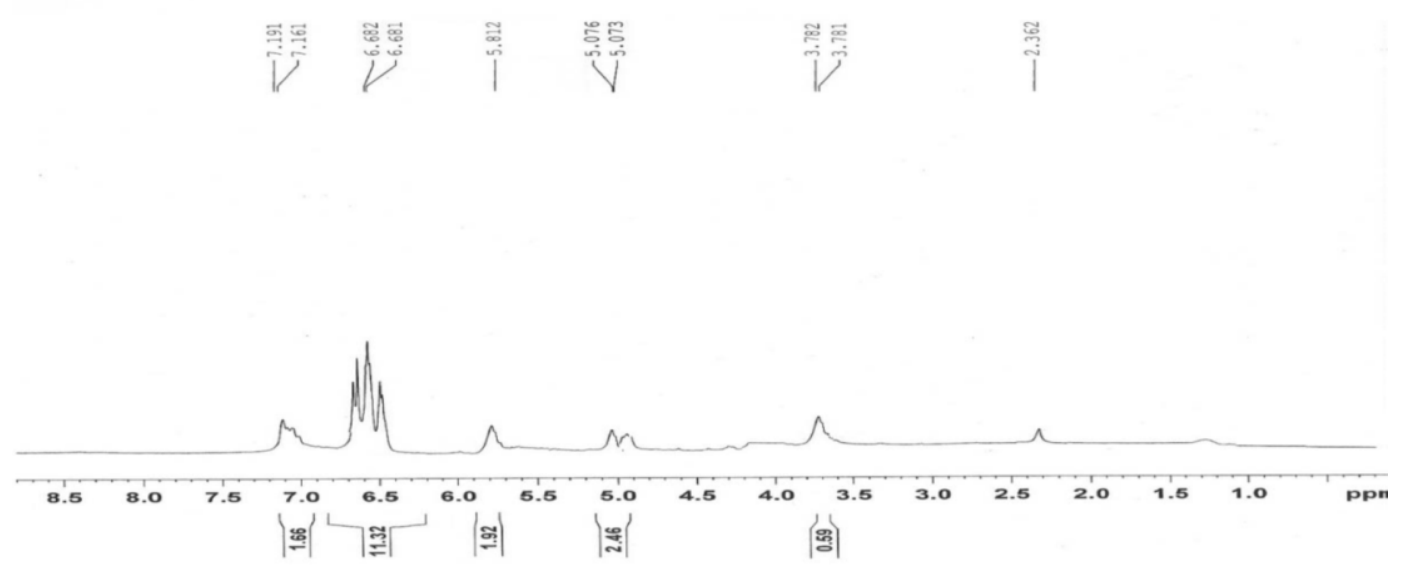

Figure 7. ${ }^{1} \mathrm{H}$ NMR Spectra of compound B. ${ }^{1} \mathrm{H}$ NMR study of compound B displayed the characteristic signals.

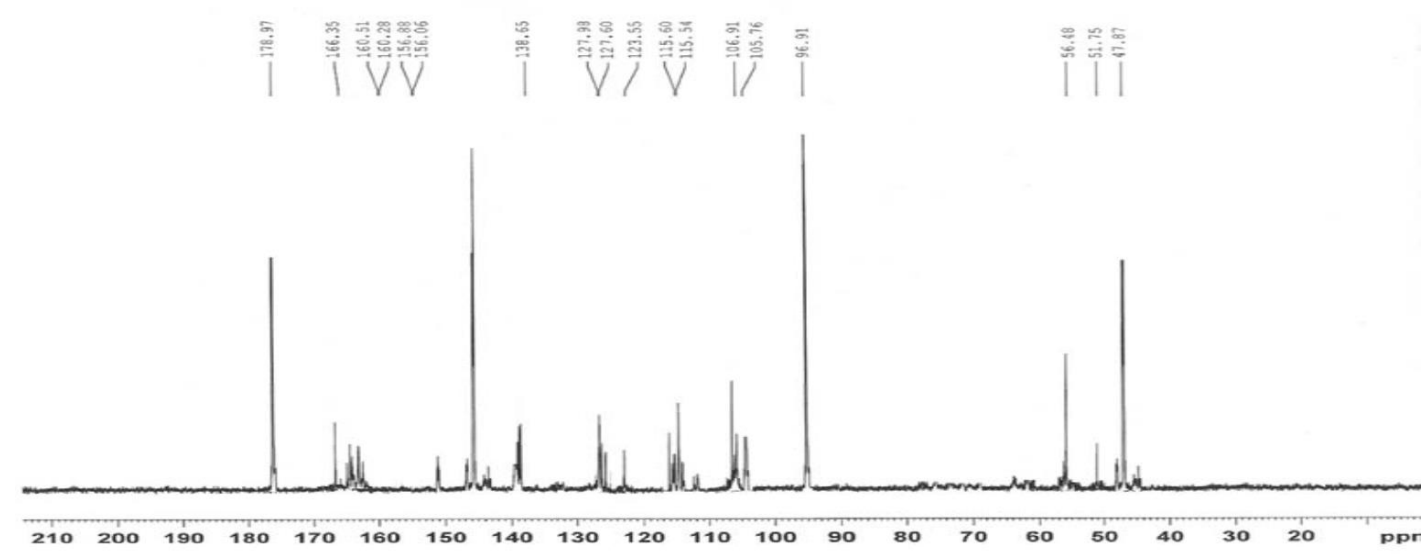

Figure 8. ${ }^{13} \mathrm{C}$ NMR Spectra of compound B. ${ }^{13} \mathrm{C}$ NMR study of compound B displayed the characteristic signals. 


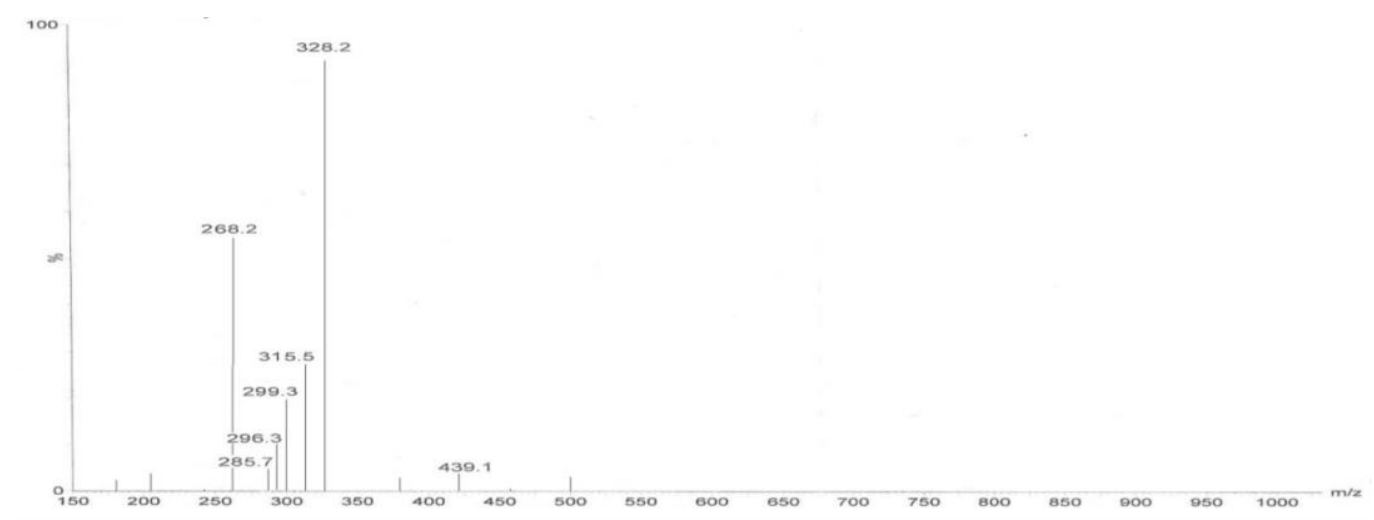

Figure 9. Mass Spectra of compound B. The mass data of compound B shows characteristic peaks.

Compound B (3,7-dimethoxy-8-methyl-4',5-dihydroxy flavone). The molecular formula of $\mathrm{C}_{18} \mathrm{H}_{16} \mathrm{O}_{6}$ was deduced from the ES-MS $\left[\mathrm{M}^{+}\right]$at $\mathrm{m} / \mathrm{z} 328$. The IR spectrum exhibited absorptions corresponding to hydroxyl $\left(3236.8 \mathrm{~cm}^{-1}\right)$ and ketone $\left(1724.9 \mathrm{~cm}^{-1}\right)$ groups. Comparing the ${ }^{1} \mathrm{H}$ NMR spectrum with that of it was found to elucidate flavone comprising of dimethoxy and a methyl group. The presence in the ${ }^{1} \mathrm{H}$ NMR spectrum of signals at $\delta 3.78 \mathrm{ppm}$ and $\delta 3.78$ indicates the presence of methoxy group in conjunction with the 13C NMR signals at $\delta 51.75$ and $56.48 \mathrm{ppm}$. The methoxy group's position at C-3 and C-7 was confirmed by the ${ }^{13} \mathrm{C}$ NMR spectrum of the signal at $\delta 138.65 \mathrm{ppm}$ and $\delta 166.84 \mathrm{ppm}$. The ${ }^{1} \mathrm{H}$ NMR spectrum of the signal at $\delta 2.36 \mathrm{ppm}$ indicates the presence of methyl proton, and it was confirmed by the ${ }^{13} \mathrm{C}$ NMR spectrum of the signal at $\delta 47.87 \mathrm{ppm}$. The methyl group's position at C-8 was confirmed by the ${ }^{13} \mathrm{C}$ NMR spectrum of the signal at $\delta 106.91 \mathrm{ppm}$. The compound is characterized as 3,7-dimethoxy-8-methyl -4',5-dihydroxy flavone.

Compound $\mathrm{C}$ was obtained as amorphous powder and it gave positive tests for flavonoids. Its melting point was found to be $242-245^{\circ} \mathrm{C}$. It gave UV $\lambda$ max (MeOH) $(\mathrm{nm}): 265.0$ and 364. The IR $\left(\mathrm{v} \mathrm{cm}^{-1}\right)$ spectrum (Figure 10) of compound $\mathrm{C}$ showed absorption bands at 3958.9 and 3872.9 (Hydrogen bonding), 3773.3 to 3536.0 (O-H, free hydroxyl group), 3022.0 (Cyclic C-H, str), 2928.0 (Ali- C-H, str), $2858.0\left(\mathrm{CH}_{2}\right.$ symmetric stretching), 1756.9 and 1721.0 ( $\mathrm{C}=\mathrm{O}$, Ketone), 1594.4, 1525.6 and 1430.6 (C-C ring stretch), 1216.3 (C-C stretching), 1026.7 (C-O-C), 928.7 (O-H, out of plane bend), 763.5, 671.1 and 627.4 (monosubstituted in aromatic ring), 582.5, 542.4 and 471.2 (out of plane ring $\mathrm{C}=\mathrm{C}$, bend). The ${ }^{1} \mathrm{H}$ NMR spectrum (Figure 11) of compound displayed the characteristic signals at $\delta_{\mathrm{H}} 5.08(\mathrm{OH}-4$ ', s), $5.08(\mathrm{OH}-$ 5, s), $5.09(\mathrm{OH}-7, \mathrm{~s}), 3.762\left(\mathrm{OCH}_{3}-3\right.$ ', s), $6.623\left(\mathrm{H}-2^{\prime}, \mathrm{s}\right), 6.55$ (H-5', d), 5.96 \& 5.97- (H-6,8, s), 6.65 (H-6', d), 5.67 (H-1", d), 3.71 (H-2",d), 3.49 (H-3”,d), 3.40 (H-4",d), 3.78 (H-5”,d), 3.79 (H-6",d), 2.06 (OH-2", 3", 4", 6").

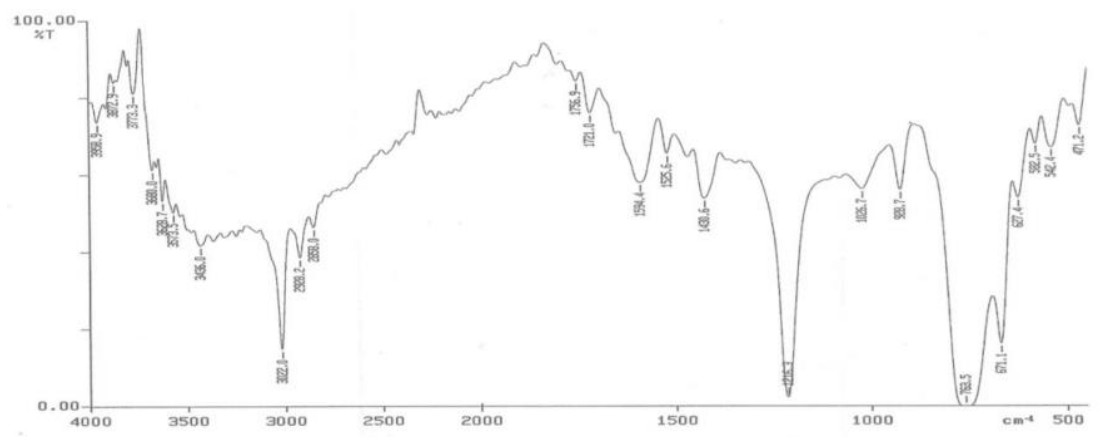

Figure 10. FTIR Spectra of compound C. FT-IR study of compound C and its characteristics absorption spectrum. Spectra show the characteristics absorption peaks of the various functional group present in the compound $\mathrm{C}$. 
The ${ }^{13} \mathrm{C}$ NMR spectrum (Figure 12) of compound displayed the characteristic signals at 2-154.05, 3-133.71, 4-178.97, 5-164.46, 6-97.87, 7-166.35, 8-97.28, 1'-122.57, 8a-160.22, 4a-105.60, 2'-114.72, 3'-151.29, 4'-144.14, $\mathrm{OCH}_{3}-56.2$, 5'-117.32, 6'-120.83, 1'-93.31, 2'73.80, 3"-73.38, 4"-71.40, 5"-77.84, 6"-62.63. The mass data (Figure 13) which showed m/z $=478(100)\left[\mathrm{M}^{+}\right]$indicative of $\mathrm{C}_{22} \mathrm{H}_{22} \mathrm{O}_{12}$. Compound $\mathrm{C}$ was isolated and its molecular formula was determined as $\mathrm{C}_{22} \mathrm{H}_{22} \mathrm{O}_{12}\left\{\mathrm{~m} / \mathrm{z}=478(100)\left[\mathrm{M}^{+}\right]\right\}$.

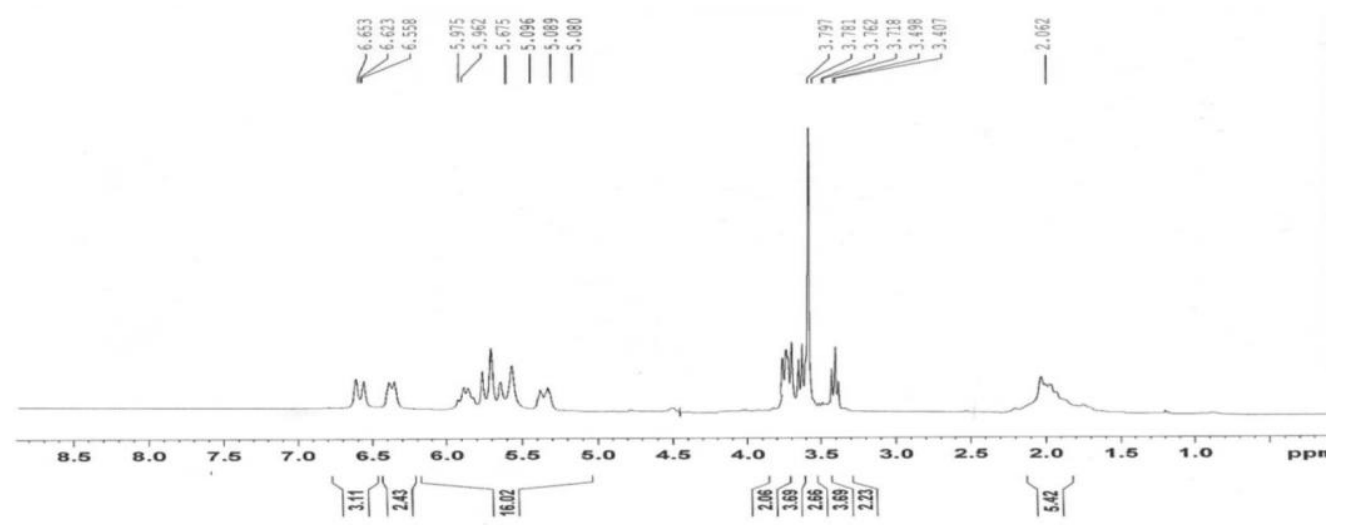

Figure 11. ${ }^{1} \mathrm{H}$ NMR Spectra of compound C. ${ }^{1} \mathrm{H}$ NMR study of compound C displayed the characteristic signals.

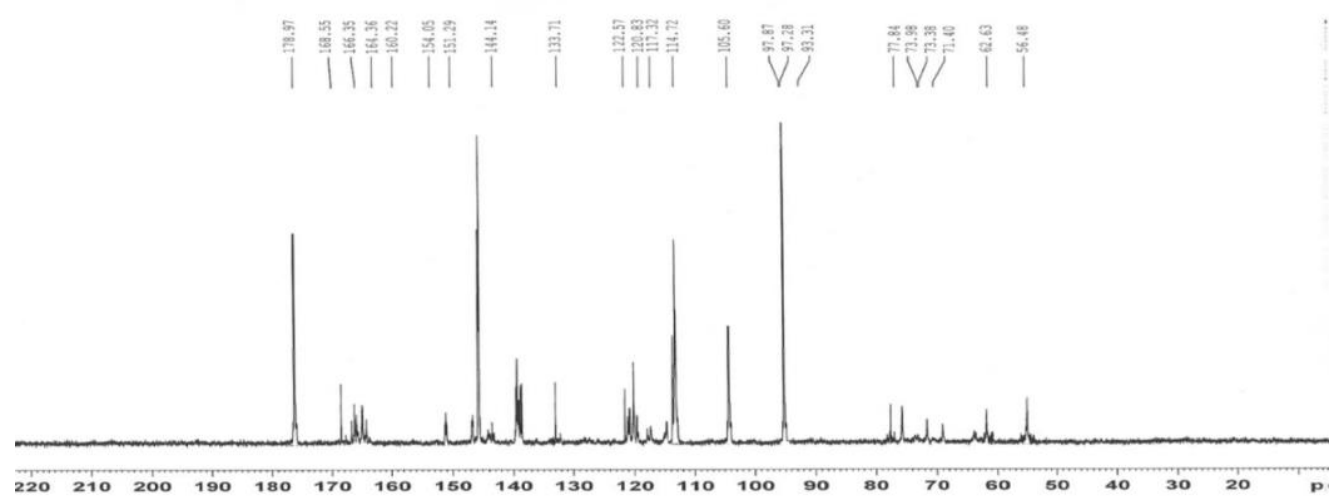

Figure 12. ${ }^{13} \mathrm{C}$ NMR Spectra of compound C. ${ }^{13} \mathrm{C}$ NMR study of compound C displayed the characteristic signals.

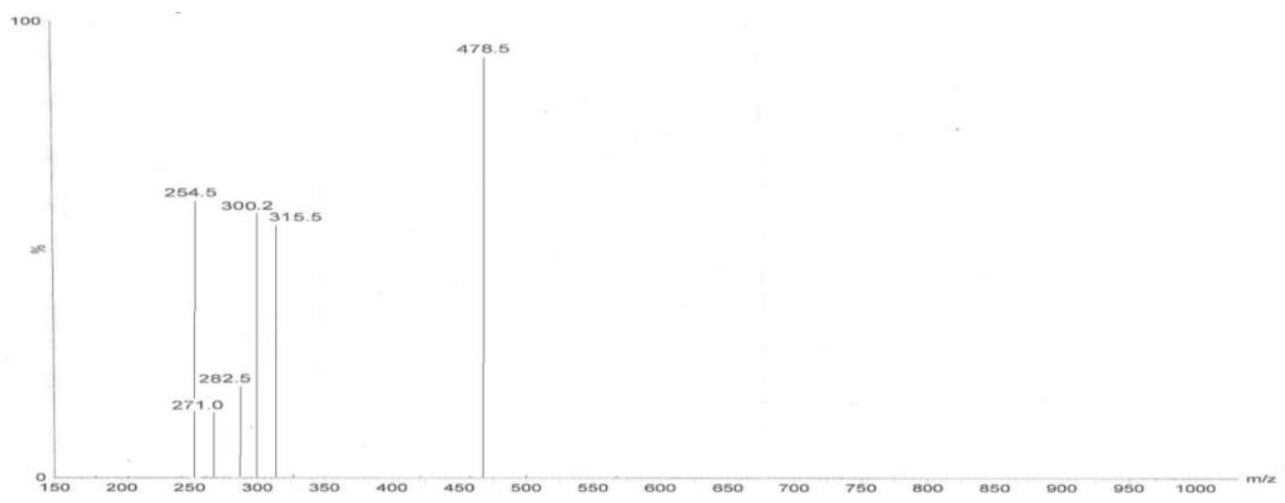

Figure 13. Mass Spectra of compound B. The mass data of compound B shows characteristic peaks.

Compound C (3'-methoxy-4',5,7-trihydroxy flavone-3-glucoside). The molecular formula of $\mathrm{C}_{22} \mathrm{H}_{22} \mathrm{O}_{12}$ was deduced from the ES-MS $\left[\mathrm{M}^{+}\right]$at $\mathrm{m} / \mathrm{z} 478$. The IR spectrum showed absorptions corresponding to hydroxyl $\left(3536.0 \mathrm{~cm}^{-1}\right)$ and ketone $\left(1721.0 \mathrm{~cm}^{-1}\right)$ groups. The chemical shift in the ${ }^{1} \mathrm{H}$ and ${ }^{13} \mathrm{C}$ NMR spectral data supported the flavone's identification compared with spectra of compound A, consisting of glycoside ring. The sugar unit was 
recognized as d-glucose from acid hydrolysis. The ${ }^{1} \mathrm{H}$ NMR spectrum of signals at $\delta 2.06 \mathrm{ppm}$ indicated the presence of hydroxyl on sugar moiety. The ${ }^{1} \mathrm{H}$ NMR data revealed C-2", C-3", C$4 "$ and C-6" as the hydroxyl sites as evidenced by downfield shifts of H-2" ( $\delta 3.71), \mathrm{H}-3$ " $(\delta$ $3.49), \mathrm{H}-4 "(\delta 3.40)$ and H-6" ( $\delta$ 3.76) signals as compared with glucose. This was further supported by the ${ }^{13} \mathrm{C}$ NMR data, which revealed upfield shifts for $\mathrm{C}-1 "$ " $(\delta 93.31 \mathrm{ppm})$ and $\mathrm{C}$ 5" ( $\delta 77.84 \mathrm{ppm})$ and the downfield shifts for C-2" ( $\delta 73.80 \mathrm{ppm}), \mathrm{C}-3 "$ ( $\delta 73.38 \mathrm{ppm}), \mathrm{C}-4 "$ ( $\delta 71.40 \mathrm{ppm})$ and C-6" ( $\delta 62.63 \mathrm{ppm})$. The compound is characterized as 3'-methoxy-4',5,7trihydroxy flavone-3-glucoside.

Four new compounds were isolated by methanolic extract of the entire plant of Ipomoea pes-caprae. Based on IR, ${ }^{1} \mathrm{H}$ NMR, ${ }^{13} \mathrm{C}$ NMR, and ES-MS spectroscopic analysis and by chemical transformation, structures and a molecular formula of compound $\mathrm{A}, \mathrm{B}$ and $\mathrm{C}$ were elucidated as 3'-methoxy-3,4',5,7-tetrahydroxy flavone $\left(\mathrm{C}_{16} \mathrm{H}_{12} \mathrm{O}_{7}\right)$, 3,7-dimethoxy-8-methyl4',5-dihydroxy flavone $\left(\mathrm{C}_{18} \mathrm{H}_{16} \mathrm{O}_{6}\right)$, and 3'-methoxy-4',5,7-trihydroxy flavone-3-glucoside $\left(\mathrm{C}_{22} \mathrm{H}_{22} \mathrm{O}_{12}\right)$ respectively. The fourth compound, compound D structurally not elucidated.

\subsection{Antitumor activity of isolated compounds.}

The antitumor activity of isolated compounds was evaluated biologically at two doses, 25 and $12.5 \mathrm{mg} / \mathrm{kg}$ body weight, for 20 days, and data were presented in Table 1 . The tumor volume of mice on $20^{\text {th }}$ days for compound A $\left(528.20 \pm 15.37 \mathrm{~mm}^{3}\right), \mathrm{B}\left(545.50 \pm 14.70 \mathrm{~mm}^{3}\right)$, $\mathrm{C}\left(438.10 \pm 15.48 \mathrm{~mm}^{3}\right), \mathrm{D}\left(732.10 \pm 15.88 \mathrm{~mm}^{3}\right)$, and standard dacarbazine $(355.23 \pm 10.79$ $\mathrm{mm}^{3}$ ) was found effective as compared to normal control $\left(1340.30 \pm 18.23 \mathrm{~mm}^{3}\right)$ at $25 \mathrm{mg} / \mathrm{kg}$ b. wt. (Fig. 14 and Table 5). All the data were analyzed and compared with the control and standard group. Experimental results are expressed as Means \pm SEM.

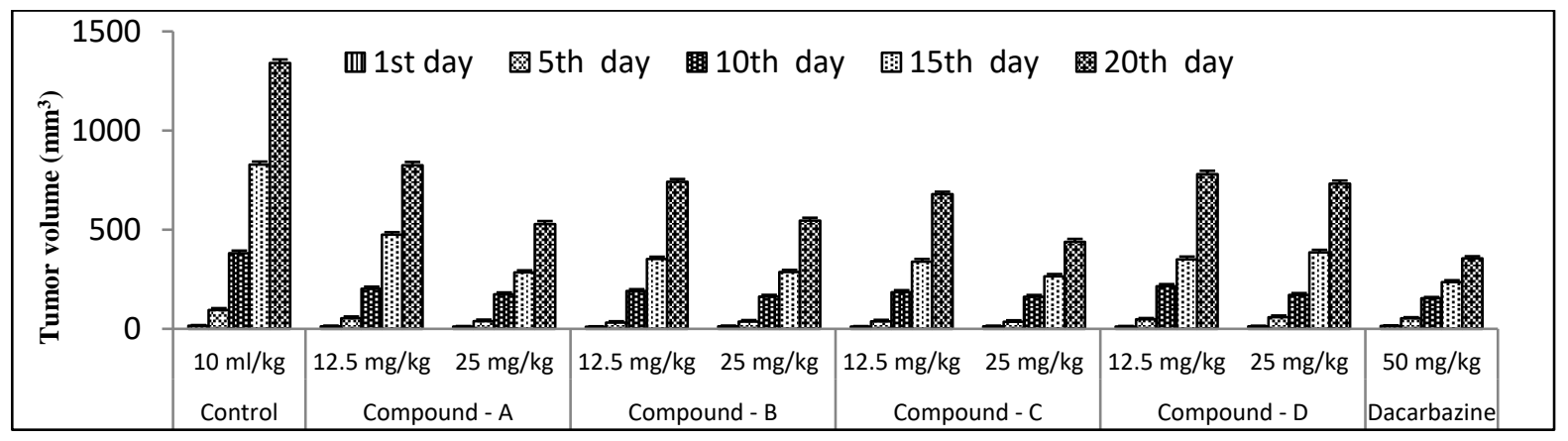

Figure 14. Tumor volume of mice subjected to isolated compound from Methanolic extract of I. pes-caprae.

The antitumor effect of compounds on melanoma tumors was significant $(\mathrm{p}<0.01)$ compared to normal control on the day of the $10^{\text {th }}$ and $20^{\text {th }}$. The schematic diagram of the present study on methanolic extract of Ipomoea pes-caprae was presented in Figure 15.

Herbals are valuable sources of novel cytotoxic agents playing a significant role in the health care system. In the Indian traditional system of medicine, many plants and their active components are used to treat tumors.

Most of them have not been scientifically evaluated, leaving enormous scope for identifying potent anticancer agents from plants. In our experiment, isolated compounds from methanolic extract of $I$. pes-caprae were found effective on melanoma tumors (B16F10). In the control group, treated normal saline, initially, slow and steady growth in tumor volume was observed with a frequently increase in tumor size after few days. Isolated compounds treated groups were not shown these types of fluctuation on tumor size. 


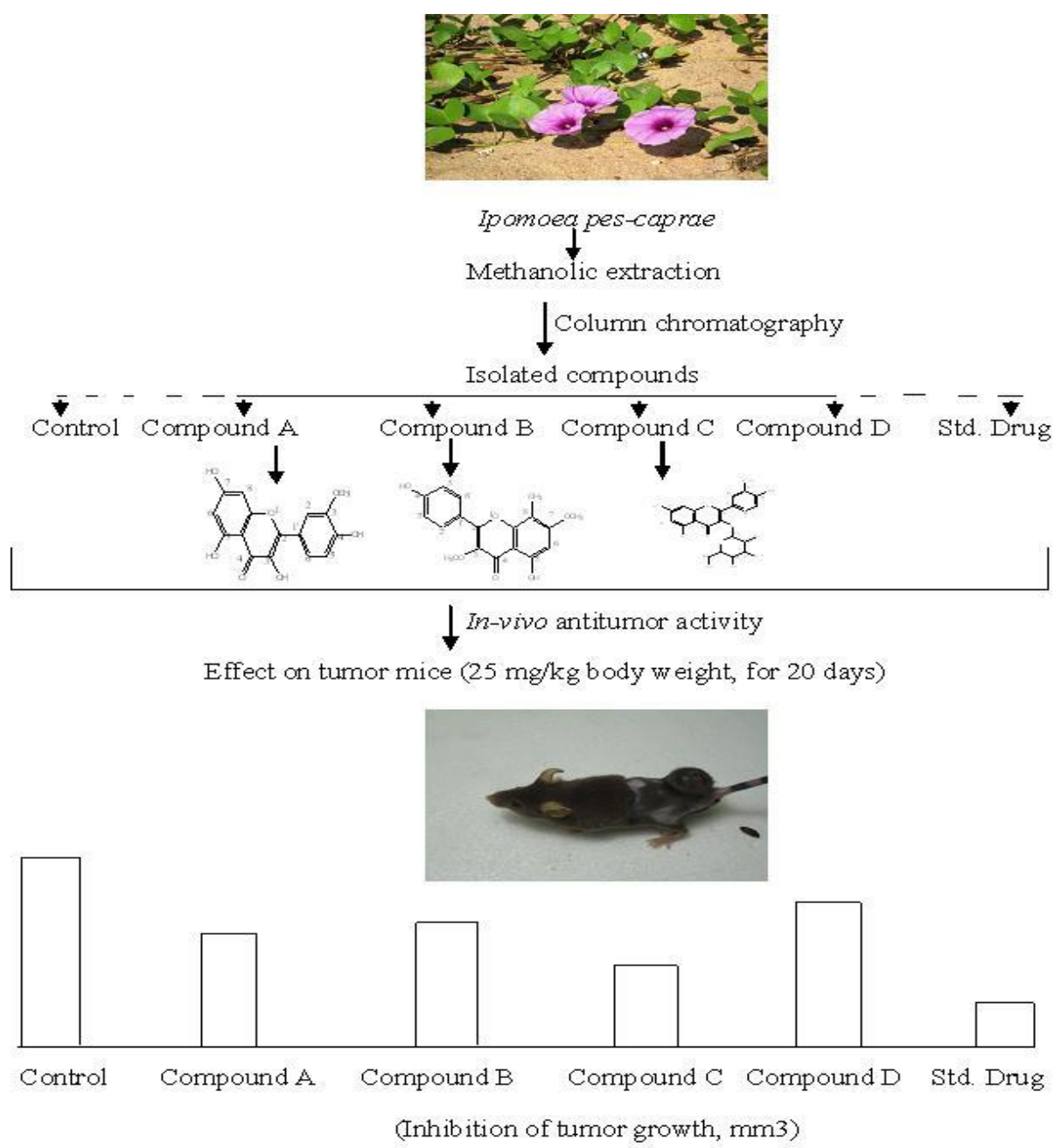

Figure 15. Schematic diagram of the present study. The diagram shows the procurement of methanolic extract of I. pes-caprae, isolated compounds, and their antitumor activity in mice.

Table 5. Tumor volume of mice subjected to isolated compounds from methanol extract of I. pes-caprae.

\begin{tabular}{|c|c|c|c|c|c|c|c|}
\hline \multirow{2}{*}{$\begin{array}{l}\text { S. } \\
\text { No. }\end{array}$} & \multirow{2}{*}{$\begin{array}{c}\text { Isolated } \\
\text { Compounds }\end{array}$} & \multirow{2}{*}{ Dose } & \multicolumn{5}{|c|}{ Tumor volume $\left(\mathrm{mm}^{3}\right)$ on Day $($ Mean \pm SEM $)$} \\
\hline & & & $1^{\text {st }}$ & $5^{\text {th }}$ & $10^{\text {th }}$ & $15^{\text {th }}$ & $20^{\text {th }}$ \\
\hline 1. & Control & $10 \mathrm{ml} / \mathrm{kg}$ & $15.50 \pm 3.44$ & $95.20 \pm 9.12$ & $381.62 \pm 12.80$ & $828.10 \pm 15.47$ & $1340.30 \pm 18.23$ \\
\hline \multirow[t]{2}{*}{2.} & \multirow[t]{2}{*}{ Compound -A } & $12.5 \mathrm{mg} / \mathrm{kg}$ & $12.60 \pm 3.45$ & $53.60 \pm 8.67$ & $202.68 \pm 10.12^{\mathrm{a}^{* *}}$ & $475.20 \pm 12.29$ & $825.10 \pm 16.48^{\mathrm{a}^{* *}}$ \\
\hline & & $25 \mathrm{mg} / \mathrm{kg}$ & $11.50 \pm 2.56$ & $38.73 \pm 7.78$ & $174.09 \pm 9.56^{\mathrm{a}^{* *}}$ & $284.23 \pm 10.78$ & $528.20 \pm 15.37^{\mathrm{a}^{* *}}$ \\
\hline \multirow[t]{2}{*}{3.} & \multirow[t]{2}{*}{ Compound -B } & $12.5 \mathrm{mg} / \mathrm{kg}$ & $10.20 \pm 2.67$ & $31.80 \pm 6.34$ & $190.40 \pm 9.58^{a^{* *}}$ & $352.40 \pm 11.28$ & $742.10 \pm 13.39^{\mathrm{a}^{* *}}$ \\
\hline & & $25 \mathrm{mg} / \mathrm{kg}$ & $13.10 \pm 3.12$ & $36.56 \pm 7.45$ & $162.68 \pm 8.68^{\mathrm{a}^{* *}}$ & $286.37 \pm 10.78$ & $545.50 \pm 14.70^{\mathrm{a}^{* *}}$ \\
\hline \multirow[t]{2}{*}{4.} & \multirow[t]{2}{*}{ Compound $-\mathrm{C}$} & $12.5 \mathrm{mg} / \mathrm{kg}$ & $11.20 \pm 2.56$ & $37.20 \pm 8.12$ & $184.32 \pm 10.59^{\mathrm{a}^{* *}}$ & $339.10 \pm 13.29$ & $679.20 \pm 12.20^{\mathrm{a}^{* * *}}$ \\
\hline & & $25 \mathrm{mg} / \mathrm{kg}$ & $12.80 \pm 3.14$ & $35.64 \pm 7.34$ & $161.48 \pm 9.24^{\mathrm{a}^{* *}}$ & $264.20 \pm 12.08$ & $438.10 \pm 15.48^{\mathrm{a}^{* * *}}$ \\
\hline \multirow[t]{2}{*}{5.} & \multirow[t]{2}{*}{ Compound -D } & $12.5 \mathrm{mg} / \mathrm{kg}$ & $11.60 \pm 2.78$ & $48.10 \pm 6.27$ & $214.20 \pm 11.26^{\mathrm{a}^{* * *}}$ & $349.80 \pm 14.68$ & $780.30 \pm 16.78^{a^{* *}}$ \\
\hline & & $25 \mathrm{mg} / \mathrm{kg}$ & $12.70 \pm 2.87$ & $58.30 \pm 8.78$ & $170.50 \pm 9.78^{a^{* * *}}$ & $385.10 \pm 13.24$ & $732.10 \pm 15.88^{a^{* * *}}$ \\
\hline 6. & Dacarbazine & $50 \mathrm{mg} / \mathrm{kg}$ & $15.15 \pm 2.34$ & $53.75 \pm 4.78$ & $154.51 \pm 5.89$ & $235.78 \pm 9.34$ & $355.23 \pm 10.79$ \\
\hline
\end{tabular}

Values shown are Mean \pm SEM, $\left(n=6\right.$ mice); Significance: ${ }^{*} \mathrm{p}<0.05,{ }^{* *} \mathrm{p}<0.01$, compared with the control (one way ANOVA followed by Dunnett's multiple comparison tests); Control vs Compound A, B, C and dacarbazine.

The higher concentration of drug dose $(25 \mathrm{mg} / \mathrm{kg}$ body weight) was found more effective in reducing tumor volume in all four compounds than $12.5 \mathrm{mg} / \mathrm{kg}$ body weight. The 
reduction of tumor volume of mice is indicating the antitumor activity of compounds. All these isolated compounds were shown flavone moiety in their internal structure. In several literature pieces, flavonoids have been reported to play an important role in treating cancers. It has been stated that some flavonoids as antioxidants, such as fisetin, apigenin, and luteolin to be potent inhibitors of cell proliferation [22]. Flavonoids like quercetin and apigenin inhibited melanoma growth and influenced the invasive and metastatic potential in mice [23]. In the present study, overall compound $\mathrm{C}$ was found more effective in reducing the tumor volume of mice due to the presence of a flavonoid glycoside ring in their main structure. Various works of literature stated that the flavonoid glycoside has antitumor activity [24, 25]. Moreover, they produce significant antitumor activity in mice on performing screening of isolated compounds' antitumor activity.

\section{Conclusions}

The present investigation's accomplishment confirms the potential of free radical scavenging activity and cytotoxic activity of I. pes-caprae. The IC50 values of methanolic and aqueous extracts were found higher, which may be due to the presence of scavenging compounds. The growth inhibition was found to be in increasing order with increasing concentration of the extracts and free radical scavenging as well as toxicity to cancer cells. The four new compounds A, B, C, and D were isolated from methanolic extract of Ipomoea pescaprae. T_Lhree compounds, namely 3'-methoxy-3,4',5,7-tetrahydroxy flavone, 3,7dimethoxy-8-methyl-4',5-dihydroxy flavone, and 3'-methoxy-4',5,7-trihydroxy flavone-3glucoside, were structurally identified. The fourth compound, Compound D was structurally not elucidated. All isolated compounds were shown antitumor potential against melanoma, whereas compound C (3'-methoxy-4',5,7-trihydroxy flavone-3-glucoside) was found more effective. Thus, the research findings reveal that I. pes-caprae as herbal medicines could be used to prevent and treat cancer disease.

\section{Funding}

This research received no external funding.

\section{Acknowledgments}

The authors express their gratitude to Central Drug Research Institute, Lucknow, India, for providing the necessary facilities for the research.

\section{Conflicts of Interest}

The authors declare no conflict of interest.

\section{References}

1. Sen, S.; Chakraborty, R. Revival, modernization and integration of Indian traditional herbal medicine in clinical practice: Importance, challenges and future. J Tradit Complement Med 2017, 7, 234-244, https://doi.org/10.1016/j.jtcme.2016.05.006.

2. Engwa, G.A. Free radicals and the role of plant phytochemicals as antioxidants against oxidative stressrelated diseases. Phytochemicals: source of antioxidants and role in disease prevention 2018, 49-73, http://dx.doi.org/10.5772/intechopen.76719. 
3. Sen, U.K.; Bhakat, R.K. Ethnobotanical study on sand-dune based medicinal plants and traditional therapies in coastal Purba Medinipur District, West Bengal, India. Eur J Med Plant 2018, 26, 1-19, https://doi.org/10.9734/EJMP/2018/46231.

4. Lalitha, P.; Sachithanandam, V.; Swarnakumar, N.S.; Sridhar, R. Review on Anti-inflammatory Properties of Mangrove plants. Asian J Pharm Res 2019, 9, 273-288, https://doi.org/10.5958/2231-5691.2019.00045.5.

5. Mohanapriya, S.; Sridevi, J. Quantification of nutrient and phytoconstituent in fresh and dehydrated Piper betel Leaf. IJAR 2020, 6, 01-04.

6. Abirami, A.; Sinsinwar, S.; Rajalakshmi, P.; Brindha, P.; Rajesh, Y.B.; Vadivel, V. Antioxidant and cytoprotective properties of loganic acid isolated from seeds of Strychnos potatorum L. against heavy metal induced toxicity in PBMC model.Drug chem toxicol 2019, 1-11, https://doi.org/10.1080/01480545.2019.1681445.

7. Ferhi, S.; Santaniello, S.; Zerizer, S.; Cruciani, S.; Fadda, A.; Sanna, D.; D'hallewin, G. Total phenols from grape leaves counteract cell proliferation and modulate apoptosis-related gene expression in MCF-7 and HepG2 human cancer cell lines. Molecules, 2019, 24, 612, https://doi.org/10.3390/molecules24030612.

8. Tiny, A.; Johney, J.; Ragunathan, R. Biogenic Synthesise of Silver nanoparticle using Syzygium samarangense leaf extract and its Antioxidant, Antibacterial and Drug Conjugation studies. J Pharm Sci Res 2020, 12, 1124-1130.

9. Solgajova, M.; Ivanisova, E.; Nozkova, J.; Francakova, H.; Toth, Z.; Drab, S. Antioxidant activity and polyphenol content of malt beverages enriched with bee pollen. J microbiol biotechnol food Sci 2020, 9, 281284.

10. Wang, L.; Xu, J.; Yan, Y.; Liu, H.; Li, F. Synthesis of gold nanoparticles from leaf Panax notoginseng and its anticancer activity in pancreatic cancer PANC-1 cell lines. Artif cells, nanomed biotechnol 2019, 47, 12161223, https://doi.org/10.1080/21691401.2019.1593852.

11. Amna, U.; Halimatussakdiah, P.W.; Saidi, N.; Nasution, R. Evaluation of cytotoxic activity from Temurui (Murraya koenigii [Linn.] Spreng) leaf extracts against HeLa cell line using MTT assay. J Adv Pharm Technol Res 2019, 10, 51-55, https://dx.doi.org/10.4103\%2Fjaptr.JAPTR_373_18.

12. Eskandari, B.; Safavi, M.; Lamardi, S.N.S.; Vazirian, M. Cytotoxic Evaluation of Daphne pontica L. Aerial Part Extracts on Three Cancerous Cell Lines by MTT Assay. Trad Integrative Med 2019, 4,58-63, https://doi.org/10.18502/tim.v4i2.1671.

13. Jang, W.J.; Jung, S.K.; Vo, T.T.L.; Jeong, C.H. Anticancer activity of paroxetine in human colon cancer cells: involvement of MET and ERBB3.J cellu mole med 2019, 23, 1106-1115, https://doi.org/10.1111/jcmm.14011.

14. World Health Organization. Managing epidemics: key facts about major deadly diseases. World Health Organization, 2018.

15. Dekebo, A.; Introductory Chapter: Plant Extracts. In Plant Extracts. IntechOpen, 2019. https://doi.org/10.5772/intechopen.85493.

16. Adhikari, P.P.; Paul, S.B. History of Indian traditional medicine: A medical inheritance. Hist 2018, 11, 421426, http://dx.doi.org/10.22159/ajpcr.2018.v11i1.21893.

17. Forni, C.; Facchiano, F.; Bartoli, M.; Pieretti, S.; Facchiano, A.; D'Arcangelo, D.; Tabolacci, C. Beneficial role of phytochemicals on oxidative stress and age-related diseases. Biomed Res Int 2019, 1-16, https://doi.org/10.1155/2019/8748253.

18. Riss, T.; Niles, A.; Moravec, R.; Karassina, N.; Vidugiriene, J. Cytotoxicity assays: In vitro methods to measure dead cells. Assay Guidance Manual [Internet] 2019.

19. Halim, A.B. Do we have a Satisfactory Cell Viability Assay? Review of the Currently CommerciallyAvailable Assays. Curr Drug Discov $\quad$ Technol 2020, 22 , https://doi.org/10.2174/1570163815666180925095433.

20. Gezici, S.; Şekeroğlu, N.; Current perspectives in the application of medicinal plants against cancer: novel therapeutic agents. Anticancer Agents Med Chem (Formerly Current Medicinal Chemistry-Anti-Cancer Agents) 2019 19,101-111, https://doi.org/10.2174/1871520619666181224121004.

21. Gezici, S. Promising anticancer activity of lavender (Lavandula angustifolia Mill.) Essential oil through induction of both apoptosis and necrosis. Ann Phytomed 2018, 7, 38-45, https://doi.org/10.21276/ap.2018.2.5.

22. Kashyap, D.; Garg, V.K.; Tuli, H.S.; Yerer, M.B.; Sak, K.; Sharma, A.K.; Sandhu, S.S. Fisetin and quercetin: promising flavonoids with chemopreventive potential. Biomol 2019,9, 174. https://doi.org/10.3390/biom9050174. 
23. Chen, X.; Xu, H.; Yu, X.; Wang, X.; Zhu, X.; Xu, X. Apigenin inhibits in vitro and in vivo tumorigenesis in cisplatin-resistant colon cancer cells by inducing autophagy, programmed cell death and targeting $\mathrm{m}$ TOR/PI3K/Akt signalling pathway. J BUON 2019, 24, 488-493.

24. Hichri, A.O.; Hichri, F.; Mastouri, M.; Brahmia, A.; Flamini, G.; Selmi, B. Study of Chemical Composition, Antibacterial and Antioxidant Activities of Rapistrum rugosum L. Essential Oils from Flowers, Leaves, and Stems. J Essent Oil Bear Plants 2019, 22, 1416-1426, https://doi.org/10.1080/0972060X.2019.1682682.

25. Ayogu, J.I.; Odoh, A.S. Prospects and therapeutic applications of cardiac glycosides in cancer remediation. ACS Comb Sci 2020, 22, 543-553, https://doi.org/10.1021/acscombsci.0c00082. 